Department of Economics- FEA/USP

\title{
Compulsory Voting and TV News Consumption
}

\author{
RAPHAEL BRUCE \\ RAFAel Costa LiMA
}

WORKING PAPER SERIES № 2015-48 


\title{
DEPARTMENT OF ECONOMICS, FEA-USP \\ WORKING PAPER № 2015-48
}

\section{Compulsory Voting and TV News Consumption}

\author{
Raphael Bruce (raphaelbruce@usp.br) \\ Rafael Costa Lima (rafael.costalima@ufpe.br)
}

\begin{abstract}
:
Do people acquire more information when they are encouraged to participate in elections? This paper presents empirical evidence on the effects of compulsory voting laws over the consumption of TV news. In Brazil, the law determines that literate citizens over the age of eighteen are subject to a number of penalties if they don't attend the ballots. This allows us to identify the causal effect of being under a compulsory voting regime on information acquisition. We find that compulsory voting has a significant and substantial positive impact on the probability of an individual to watch Brazil's main TV newscast. Additionally, the effect is stronger for poor voters and for individuals who have neutral evaluations of the incumbent president. Our results are restricted to young voters who just turned eighteen and are robust to different polynomials and bandwidth lengths.
\end{abstract}

Keywords: Compulsory voting; Information; Media; Brazil

IEL Codes: D72; D83; L82. 


\title{
Compulsory Voting and TV News Consumption*
}

\author{
Raphael Bruce ${ }^{\dagger} \quad$ Rafael Costa Lima ${ }^{\ddagger}$
}

June, 2017

\begin{abstract}
Do people acquire more information when they are encouraged to participate in elections? This paper presents empirical evidence on the effects of compulsory voting laws over the consumption of TV news. In Brazil, the law determines that literate citizens over the age of eighteen are subject to a number of penalties if they don't attend the ballots. This allows us to identify the causal effect of being under a compulsory voting regime on information acquisition. We find that compulsory voting has a significant and substantial positive impact on the probability of an individual to watch Brazil's main TV newscast. Additionally, the effect is stronger for poor voters and for individuals who have neutral evaluations of the incumbent president. Our results are restricted to young voters who just turned eighteen and are robust to different polynomials and bandwidth lengths.
\end{abstract}

JEL Codes: D72, D83, L82

Keywords: Compulsory voting, Information, Media, Brazil

\footnotetext{
${ }^{*}$ We would like to thank Mitra Akhtari, Filipe Campante, Raphael Corbi, Fernanda Estevan, Leopoldo Fergusson, Pedro Forquesato, Thomas Fujiwara, Horacio Larreguy, Marcos Nakaguma, Santiago Olivella, Breno Sampaio and Graziella Testa for the helpful comments and discussions. We are also thankful to participants at the 2015 MPSA Conference, the Harvard Positive Political Economy Workshop, PET 16 Rio, the 2016 MIPP Political Economy Workshop at Santiago, the 2016 Meeting of the Brazilian Econometric Society, RIDGE/LACEA-PEG 2017, and seminar participants at UFPE for the comments and suggestions on previous versions of this paper. Raphael Bruce gratefully acknowledges FAPESP for the financial support and the Taubman Center at Harvard University for the hospitality.

${ }^{\dagger}$ University of São Paulo - Department of Economics. Address: Av. Prof. Luciano Gualberto, 908, São Paulo - SP, 05508-010, Brazil. E-mail: raphaelbruce@usp.br

${ }_{\ddagger}^{\ddagger}$ Federal University of Pernambuco - Department of Economics. Address: Av. dos Economistas, Recife - PE, 50740-580, Brazil. E-mail: rafael.costalima@ufpe.br
} 


\section{Introduction}

On March 18, 2015 U.S. President Barack Obama publicly endorsed compulsory voting as a way to increase the historically low voter turnout on U.S. elections. He stated that "In Australia, and some other countries, there's mandatory voting. It would be transformative if everybody voted... it would completely change the political map in this country, because the people who tend not to vote are young; they're lower income; they're skewed more heavily towards immigrant groups and minority groups". ${ }^{1}$ President Obama's opinions echo Arend Lijphart's 1996 Presidential Address to the American Political Science Association, in which he defended compulsion as a way to solve the problem of unequal political participation in elections. He argued that penalizing abstention would increase turnout, political knowledge, and political engagement in the electorate (Lijphart, 1997). Our interest is related to the last two effects. More specifically, we study how inducing turnout through compulsory voting affects information acquisition.

One of the main arguments against compulsory voting laws is based on the idea that, even if such rule had a positive impact on turnout, it would have a perverse effect on the outcome of the elections (Saunders, 2012; Singh, 2016). The simple idea is that, by increasing the share of uninformed individuals turning out to vote, electoral choices would be worse than the ones made under voluntary voting. Shineman (2016) points that this line of reasoning was often used during the debates in US Congress regarding the National Voter Registration Act. The author notes that members of the Congress and of the media raised concern that lowering the cost of voting would lead to a decrease in voter competence. Central to the idea that increasing turnout may lead to an increase in uninformed voting is the assumption that voters do not change their consumption of information when the costs and benefits of turning out are altered. In this paper we challenge this assumption.

Compulsory voting (henceforth, "CV") is an important feature of 22 different countries, yet we turn our attention to Brazil. The Brazilian electoral law determines that every literate citizen above eighteen and younger than seventy years old by the day of the elections is subject to a number of penalties in case of failing to attend an official polling station and casting a ballot. The age-based rule that determines who's under CV regime and who's not enable us to measure the causal effect of the law on the consumption of TV newscasts. We implement a regression discontinuity design (RDD) using a novel data set on the Brazilian population's media-related habits.

Results show that individuals who are being exposed to the penalties for the first time are on average 13.6 percentage points more likely to watch Rede Globo's Jornal Nacional, Brazil's most trusted newscast. This effect represents a $70 \%$ increase relative to when they were not subject to abstention fines. The result is restricted to Jornal Nacional and not to other newscasts or TV shows. Additionally, the effect is more robust for low income individuals than for those with high income. We also find that voters with neutral evaluations of the incumbent presidency significantly increase their consumption of TV news when exposed to the abstention penalties. No impact is found, though, for elderly voters who are transitioning into a voluntary voting regime at the age of seventy, high income voters or those who have more polarized evaluations of the federal government. Our results are also robust to different polynomial orders and bandwidth lengths.

The young voters preference towards Jornal Nacional over other newscasts highlights the role credibility plays when it comes to information acquisition. ${ }^{2}$ With an audience share of $70 \%$, the equivalent to

\footnotetext{
${ }^{1}$ For the full transcript see: https://obamawhitehouse.archives.gov/the-press-office/2015/03/18/remarks-president-cityclub-cleveland

${ }^{2}$ There's a still small but growing literature on the how sources' credibility shapes the way voters acquire and process information. Chiang and Knight (2011) show how the impact of newspaper endorsements on voter's opinion varies according
} 
31 million viewers, Jornal Nacional is the most viewed and most trusted Brazilian television newscast. On air from Monday to Saturday at 8:30 pm, it premiered on September 1, 1969, and since then has become a daily presence in the life of Brazilian families. According to Porto (2007a), almost half of its length focuses on political, economic and social themes, making it a natural source of information for issues that are salient to voters.

The existing evidence regarding compulsory voting and information acquisition is still mixed, and relies mostly on cross-country comparisons or laboratory experiments. Using data from the 1989 EuroBarometer post-election survey, Gordon and Segura (1997) measure the political sophistication of each respondent in the twelve nations of the pre-1995 European Union. They find a positive correlation between the presence of compulsory voting legislation and political sophistication. Grosser and Seebauer (2016) find that participants in a laboratory experiment are more likely to acquire costly information when not given the option to abstain from elections. On the other hand, Loewen et al. (2008) and Birch (2009) find no evidence on the relation between being under compulsory voting and being more informed.

Recently, new research has emerged providing within-country evidence on second-order effects of increasing the cost of abstention. de Leon and Rizzi (2014) focus on the impact of compulsory voting on knowledge about political issues, such as candidates' names and political platforms. Using a selfconducted survey the authors find that the turnout increase from compulsory voting is not followed by an increase in the consumption of political information or an increase in political knowledge. The survey was applied to four high schools in the metropolitan area of the city of São Paulo, Brazil, and to freshmen students at the University of São Paulo, a highly selective public university. Using data on a survey administered to young voters taking the high-school national exit exam in Brazil (ENEM), Holbein and Rangel (2016) show that CV has no impact on the search for information on written materials such as newspapers and magazines. The authors emphasize, however, that this does not preclude that young voter's may be looking for political information on other sources like TV and the internet. León (2017) finds similar results for Peru using a field experiment. The author combines survey information with a change in the peruvian voting law in order to gauge how individuals' political behavior is affected by the size of the abstention fine. He finds that those who stop voting because they face lower abstention costs do not acquire informational differentially than those who face a higher fine. Using a randomized field experiment applied on the San Francisco Municipal Elections of 2011, Shineman (2016) finds that voters who were mobilized to vote became more informed about the content of the election. Even though this paper does not focus on CV itself, the author presents evidence that information acquisition can be endogenous to the costs and benefits of voting.

Our paper complements the findings above. Taking advantage of a nationally representative survey on media habits, we focus on voters' attempt to gather more information. Even though we cannot evaluate if the voters actually learn relevant information when induced to vote, we find evidence that they seek broad information on salient topics ranging from the state of economy, crime, health to educational policy, all of them covered by Jornal Nacional. Moreover, we find that the consumption of information has heterogeneous effects for individuals with different socioeconomic status and degrees of political polarization. Our results highlight how changes in the calculus of voting can ultimately lead to changes in media habits in one of the world's largest democracies.

This paper also contributes to the growing literature on the relation between the media and political outcomes. Most studies so far explore this link within consolidated democracies such as the ones found

with the degree and the direction of the endorser's bias. Alt et al. (2016) find that economic information acquired from the Danish Central Bank causes voters to better update their belief when compared to information received from the government or political parties. 
in the U.S. or Scandinavian countries. ${ }^{3}$ As pointed by Sobbrio (2014), there's a need for more work on different institutional settings. Brazil, being the largest democracy in Latin America and the home of Rede Globo, the third largest commercial television network in the world, provides an interesting backdrop for our analysis (Ciochetto, 2013).

A significant amount of the research focuses on answering how media consumption affects voter turnout. Evidence is obtained by taking advantage of exogenous changes in media exposure due to the entry of a new technology or a media channel. For example Gentzkow (2006) shows how the introduction of television in different markets in the United States is partially responsible for the decline in turnout and political knowledge since the 1950s. Other papers show how the exposure to different networks with clear bias or target audience mobilizes specific constituencies (DellaVigna and Kaplan, 2007; OberholzerGee and Waldfogel, 2009; Enikolopov et al., 2011). The bulk of the literature remains silent, however, about the converse question: does inducing turnout increases media consumption? Such answer would allow us to better understand how information is aggregated in large elections (Martinelli, 2006). By assessing what is the impact of the compulsory voting law on information acquisition in the form of TV newscasts, we address this important issue.

The remainder of the paper is organized as follows. Section 2 presents a theoretical framework that links compulsory voting to information acquisition. Section 3 provides basic background information on the mandatory voting law in Brazil and on Jornal Nacional, and Section 4 describes the data and our empirical strategy. The results are presented in Section 5, followed by robustness checks and placebo tests in Section 6 and the analysis of heterogeneous effects in Section 7 . Section 8 concludes the paper.

\section{Theoretical Framework}

\subsection{Benchmark model}

Our model follows closely the uncertain-voter model proposed by Degan (2006), who studies the relationship between policy preferences, turnout and information acquisition. We expand the model to analyze how abstention fines affect voting preferences, turnout decisions and, ultimately, the demand for information.

There are two candidates $c \in\{L, R\}$ in this setting. Each one is running on a platform $y_{c} \in Y_{c} \subset Y$, where $Y$ is the left-right policy space. Citizens are distributed across a continuum of measure 1 , and each citizen $j$ has a preferred platform $y_{j} \in Y$. They evaluate candidates according to the following payoff function:

$$
u_{j}^{c}=-\left(y_{j}-y_{c}\right)^{2} .
$$

Citizens are uncertain about the candidates' platforms which, from their perspective, are random variables $\left(\tilde{y}_{L}, \tilde{y}_{R}\right)$ following a distribution $F$ over $Y_{L} \times Y_{R}$. For the sake of simplicity, we assume that $Y_{L}=[-1,0], Y_{R}=[0,1]$ and that $F($.$) is symmetric around zero.$

Each citizen $j^{\prime}$ s information set is denoted by $\Omega_{j} \in \Omega=\left\{F,\left(y_{L}, y_{R}\right)\right\}$, which is the the main source of heterogeneity between them. Citizens can pay to acquire information. The choice consists in paying a cost $\delta$ to receive a signal that reveals the candidates' true platform with probability $p \in(0,1]$ (i.e. she learns exact platforms $\left.\Omega_{j}=\left(y_{L}, y_{R}\right)\right)$. In case the citizen does not pay the cost, or if the signal is not informative, she remains uninformed and makes her decisions according to the distribution $F$.

\footnotetext{
${ }^{3}$ See DellaVigna and Ferrara (2015) for a detailed survey.
} 
A central feature of this model is that uncertainty about the candidates' platforms generates disutility from possible voting mistakes. More precisely, the behavioral cost of voting for candidate $L(R)$ is defined as the expected utility loss generated by the possibility of voting for him when candidate $R(L)$ would generate greater utility. That is:

$$
C_{j}\left(L ; y_{j}, \Omega_{j}\right)=\mathbb{E}\left[\mathbf{1}\left\{u_{j}^{L}<u_{j}^{R}\right\} \cdot\left(u_{j}^{R}-u_{j}^{L}\right) \mid \Omega_{i}\right] .
$$

Notice that when the individual is not certain about each candidate's policy position, they incur on a positive expected $\operatorname{cost} C_{j}() \geq$.0 . Those who have successfully acquired information about the candidates' platforms always pick the correct candidate and obtain $C_{j}()=$.0 . Every citizen also has a civic-duty benefit $d_{j} \geq 0$ from attending the ballots at the day of the election. As in Degan (2006), we assume $d_{j}$ is exogenous. It does not depend on information or on the chosen candidate.

The citizen's decision making process is a three stage problem. In the first stage she must choose whether or not to acquire information. That is, to choose $i \in\{0,1\}$ where $i_{j}=1(i=0)$ means information was (not) acquired. Next, given her information set, she chooses whether or not to turn out to vote. This choice is expressed by the dummy $t_{j} \in\{0,1\}$, where $t=1(t=0)$ means she does (not) turn out to vote. Lastly, the voter must decide on whom to vote for, represented by the variable $v_{j} \in\{L, R\}$.

The solution to this problem is given by the tuple $\left(v_{j}^{*}, t_{j}^{*}, i_{j}^{*}\right)$ and it is found by solving the model backwards. We start with the voting decision. In this stage, citizen $j$ must choose between $L$ and $R$ according to the following voting rule:

$$
v^{*}\left(y_{j}, \Omega_{j}\right)= \begin{cases}L, & \text { if } C_{j}\left(L ; y_{j}, \Omega_{j}\right)<C_{j}\left(R ; y_{j}, \Omega_{j}\right), \\ R, & \text { if } C_{j}\left(R ; y_{j}, \Omega_{j}\right)<C_{j}\left(L ; y_{j}, \Omega_{j}\right) .\end{cases}
$$

If $C_{j}\left(R ; y_{j}, \Omega_{j}\right)=C_{j}\left(L ; y_{j}, \Omega_{j}\right)$, the agent randomizes. From Degan (2006), we know that stating that $j$ votes for $L$ if and only if $C_{j}\left(L ; y_{j}, \Omega_{j}\right)-C_{j}\left(R ; y_{j}, \Omega_{j}\right)<0$ is equivalent to stating that she votes for $L$ if and only if $\mathbb{E}\left[\left(u_{j}^{L}-u_{j}^{R}\right) \mid \Omega_{j}\right]>0$. Substituting the citizen's utility function into this last inequality, and taking the binding condition, gives the ideological cutoff point $\tau\left(\Omega_{J}\right)=\mathbb{E}\left[\left(y_{R}^{2}-y_{L}^{2}\right) \mid \Omega_{j}\right] / 2 \mathbb{E}\left[\left(y_{R}-y_{L}\right) \mid \Omega_{j}\right]$. Moreover, we also know the $\operatorname{cost} C_{j}(\cdot)$ is single peaked at zero, and it is zero for all $|y| \geq 1 / 2$.

Next, we proceed to the turnout decision. Given the solution to the choice of candidate, which gives $C_{j}\left(y_{j}, \Omega_{j}\right) \equiv C_{j}\left(v_{j}^{*}\left(y_{j}, \Omega_{j}\right)\right)$, citizen $j$ chooses whether or not to turn out in the day of the election. The benefit of turning out to vote is given by $d_{j}$, regardless of choice of candidate. The cost of turning out is given by $C_{j}\left(v_{j}^{*}\left(y_{j}, \Omega_{j}\right)\right)$. The decision is, then, taken according to the following cutoff rule:

$$
t^{*}\left(y_{j}, \Omega_{j}\right)= \begin{cases}1, & \text { if } C_{j}\left(v_{j}^{*}\left(y_{j}, \Omega_{j}\right)\right)-d_{j}<0 \\ 0, & \text { if } C_{j}\left(v_{j}^{*}\left(y_{j}, \Omega_{j}\right)\right)-d_{j} \geq 0\end{cases}
$$

If the net benefit of casting a ballot (i.e. the opportunity cost of abstention) is positive, citizen $j$ will turnout, otherwise she stays at home. Notice that an informed citizen always turns out since his cost is zero when voting for the favorite candidate.

Finally, we turn to the first stage. The citizen must decide whether or not to acquire information. She compares the costs and benefits from acquiring information, anticipating the optimal turn out and voting decisions. Let us define $C_{j} \equiv C_{j}\left(v_{j}^{*}\left(y_{j}, \Omega_{j}=\left\{F\left(y_{L}, y_{R}\right)\right\}\right)\right)$ as the voting cost after failing to acquire information. There are two relevant scenarios, one where the civic duty $d_{j} \geq C_{j}$, and the other where $d_{j}<C_{j}$. 
For $d_{j}<C_{j}$, the voting cost of an uninformed voter is greater than the civic duty benefit of attending the ballot. Without information, the citizen will not turn out to vote. In such case, she can acquire information in order to reduce her voting cost. She does so whenever the expected benefit of turning out is greater than the cost of acquiring information, that is, whenever $p d_{j}-\delta \geq 0$. We can also write this inequality as $d_{j} \geq \delta / p$. In case $d_{j}<\delta / p$, the citizen does not invest in information acquisition.

If, on the other hand, $d_{j} \geq C_{j}$, then the voter always turns out to vote. She may still try to acquire information, since it reduces the voting cost. The expected payoff she gets from investing in information acquisition is given by $d_{j}-(1-p) C_{j}-\delta$. The payoff from not investing to acquiring information, in turn, is given by $d_{j}-C_{j}$. Comparing the two, we find that the citizen acquires information whenever $C_{j} \geq \delta / p$. Combining the two cases, gives the following rule for information acquisition:

$$
i^{*}\left(d_{j}, \delta, p\right)= \begin{cases}1, & \text { if } d_{j}, C_{j} \geq \frac{\delta}{p} \\ 0, & \text { if otherwise }\end{cases}
$$

To sum up, Degan (2006) points that there are four possible solutions to this decision problem according to the parameters space. When $d_{j} \geq C_{j} \geq \delta / p$, the citizen turns out to vote $\left(t_{j}^{*}=1\right)$ and invests to acquire information $\left(i_{j}^{*}=1\right)$. This group of individuals is referred to as the weak partisans. When $d_{j} \geq \delta / p>C_{j}$, the citizen turns out to vote $\left(t_{j}^{*}=1\right)$ but does not acquire information $\left(i^{*}=0\right)$. Those are the strong partisans. When $C_{j}>d_{j} \geq \delta / p$ the citizen invests to acquire information $\left(i^{*}=1\right)$ but only turns out to vote if the investment is rewarded and she learns the politicians' platforms. They are the middle of the road voters. Finally, if $C_{j}>\delta / p>d_{j}$ or $\delta / p>C_{j}>d_{j}$, the citizen never tries to acquire information $\left(i_{j}^{*}=0\right)$ or turns out to vote $\left(t_{j}^{*}=0\right){ }^{4}$

Our interest is to analyze the effects of compulsory voting laws on the decision to become informed. In order to do so, we must include an abstention penalty in our benchmark model. That is, citizens must pay an additional cost when they fail to turn out.

\subsection{Compulsory Voting}

Under compulsory voting, citizens must now incur in a cost $M_{j}$ if they choose to abstain. The voter's expected payoff is given by:

$$
t_{j}\left[d_{j}-C_{j}\right]-\left(1-t_{j}\right) M_{j}-\delta \cdot i_{j}
$$

Which can be rewritten as:

$$
t_{j}\left[\hat{d}_{j}-C_{j}\right]-M_{j}-\delta \cdot i_{j}
$$

where $\hat{d}_{j}=d_{j}+M_{j}$ is the induced benefit from attending the ballots and $\hat{d}_{j}-C_{j}$ is the opportunity cost of abstention under compulsory voting. The solution to this problem, as in our benchmark setup, can be found by solving the model backwards. Notice that, after defining $\hat{d}_{j}$ in equation $(7)$, the remaining term $M_{j}$ is a constant on the citizen's preferences. As such, it does not affect any stage of the decision. The induced benefit of attending the ballots $\hat{d}_{j}$, on the other hand, changes the decision when compared to the former model with a plain $d_{j}$. That said, all the former results hold by simply replacing $d_{j}$ by $\hat{d}_{j}$ is the previous subsection. The new results are presented in the following proposition:

Proposition 2.1. Let $M_{j}>0$ and $\hat{d}_{j}=d_{j}+M_{j}$. Compulsory voting leads to:

\footnotetext{
${ }^{4}$ For further details on the proofs of these results, see Degan (2006).
} 
1. An increase in turnout for citizens $j$ with $C_{j} \geq d_{j}$ and either $\hat{d}_{j}>C_{j} \geq d_{j}$ or $C_{j}>\hat{d}_{j}>\delta / p>d_{j}$.

2. An increase in the investment information for those with $\hat{d}_{j}, C_{j}>\frac{\delta}{p} \geq d_{j}$.

Proof. To prove item 1 we notice that citizens with $d_{j} \geq C_{j}$ already turn out to vote. So, compulsory voting is irrelevant for their decision since $\hat{d}_{j}>d_{j}>C_{j}$. Citizens with $C_{j}>d_{j}$ either do not vote $\left(\delta / p>d_{j}\right)$ or vote only if get information $\left(d_{j} \geq \delta / p\right)$. In this last case, the citizen is, without compulsory voting, acquiring information and turning out if this acquisition is successful. The increase in the induced benefit $\hat{d}_{j}$ may change her decision into turning out irrespective of the result of information acquisition. That is the case whenever $\hat{d}_{j} \geq C_{j}>d_{j}$. Turnout increases in expected terms.

In the second case, citizens do not vote without compulsory voting. As a result of the higher induced benefit from turn out, they may change their decision and vote irrespective of information $\left(\hat{d}_{j} \geq C_{j}>d_{j}\right)$ or they may gather information and vote if acquisition is successful (when $C_{j}>\hat{d}_{j} \geq \delta / p>d_{j}$ ). In both cases the range of parameters that lead to turn out $\left(t_{j}^{*}=1\right)$ increases.

To prove item 2 , remember that when $d_{j}, C_{j} \geq \delta / p$ the citizens acquire information. In such case their decision is unaffected by compulsion. Since compulsion does not affect the cost of voting, the only relevant situation is of those citizens with $C_{j}>\delta / p>d_{j}$ where also $\hat{d}_{j} \geq \delta / p$. Those are the voters which are induced to acquire information from compulsory voting laws. All other citizens' decision remain unaltered.

Notice from the proof that compulsory voting leads to changes on the composition of the electorate. The proof of item 1 shows that some of the middle of the road citizens may become partisans and also that and some completely uninterested citizens may become middle of the road or even weak partisans. The proof of item 2 shows that completely uninterested citizens may become middle of the road. Still, some of the middle of the road may become weak partisans, yet both groups are gathering information, so the decision regarding information acquisition is unchanged.

The predictions are straightforward. Turnout increases due to compulsory voting, as expected and confirmed bye empirical evidence previously discussed. Also, information acquisition increases due to compulsory voting, a result which is supported by our empirical evidence. The model still predicts a change in the composition of the electorate, with weak partisans and middle of the road groups increasing in size. We partly confirm this result empirically since when we find that the effect of CV over information consumption is greater for individuals with intermediary evaluations of the incumbent government.

\section{Institutional Background}

\subsection{The Compulsory Voting Law}

Brazil's current compulsory voting legislation started with the promulgation of the Brazilian Constitution of 1988. It states that every literate citizen older than 18 and younger than 70 years old must attend the ballots on election day or justify its absence in a special court. Citizens older than 16 and younger than 18 are allowed to register to vote, but do not face any consequence if they don't. ${ }^{5}$ If an individual fails to justify her absence, she must pay a small fine of $\mathrm{R} \$ 3.00$ (roughly 0.90 dollars), which can be multiplied tenfold according to the decision of the judge handling the case. Those who fail to justify absence three times are also subject to a number of sanctions, such as not being allowed to issue a new

\footnotetext{
${ }^{5}$ According to the Superior Electoral Court of Brazil (TSE), only one fourth of individuals under eighteen years registered to vote in the 2014 elections.
} 
ID or passport, being ineligible for cash transfer programs, credit by financial institutions maintained by the government, public jobs and public education. ${ }^{6}$

There's also reasons to believe that other non-fiduciary elements may induce turnout. First, citizens are allocated to ballots according to their postal code. This means that people who live in the same neighborhood will vote near their home on the same place, on the same day. Recent studies stress the fact that individuals care about being seen as participant citizens, and this concern about their social image constitutes a driving force behind voter turnout (Gerber et al., 2008; Funk, 2010; DellaVigna et al., 2017). In the light of these findings, an abstention in the day of an election may be socially costly for citizens who worry about how they will be seen in their local community. Furthermore, the first and second round of the elections are held on the first and last Sunday of October, respectively. Since an individual who failed to justify his absence must pay the fine on a regional electoral court during business hours, it's likely that the opportunity cost of attending the ballots is lower than the one of having to deal with the bureaucracy on weekdays. Also, unlike the ballot, the court is not necessarily located near from where the person who abstained lives.

The abstention rates in Brazil are also low. For example, in the 2012 elections the average abstention in Brazilian municipalities was $14 \%$, with $9 \%$ invalid votes cast for mayor and $5 \%$ invalid votes for city council. This leads us to believe that the law is indeed enforced and turnout is high in the presence of compulsory voting. Recent research by Cepaluni and Hidalgo (2016) using the full Brazilian voter file comprising of 140 million individuals shows that Brazilian compulsory voting law has a sizable causal impact on turnout, in line with the findings of de Leon and Rizzi (2014).

\subsection{Rede Globo and Jornal Nacional}

Television plays a major role in the life of brazilian citizens. According to the 2006 National Household Sample Survey (PNAD), 93\% of the households owned at least one television set. In Fava and ArendsKuenning (2013), the authors present evidence that, among poor households, there is a higher probability that a family owns a color TV set than a refrigerator, despite both representing a similar cost.According to the Brazilian Media Survey of 2014, a vast majority of the population has the TV as their main source of information, as it can be seen in Figure 1. This is consistent with the findings of Kennedy and Prat (2017) on media consumption patterns around the world. Even though the internet plays a larger role for the younger population, shows that it still fares well behind television as young individuals main source of information. ${ }^{7}$ Using data from a different survey, Mesquita (2010b) finds that TV is also preferred by $65.4 \%$ of the population as their main source of news on political issues.

\footnotetext{
${ }^{6}$ For more information, see http://www.tse.jus.br/eleitor/servicos/justificativa-eleitoral (in Portuguese).

${ }^{7}$ Even if one accepts that the internet has a growing presence in the life of young adults, it is important to note that consuming information doesn't necessarily mean trusting it. In Figure A1 and A2 we show that TV and traditional media are still more a reliable source of information for young adults than online platforms such as websites, blogs and social media
} 
Figure 1: Favorite source of information.
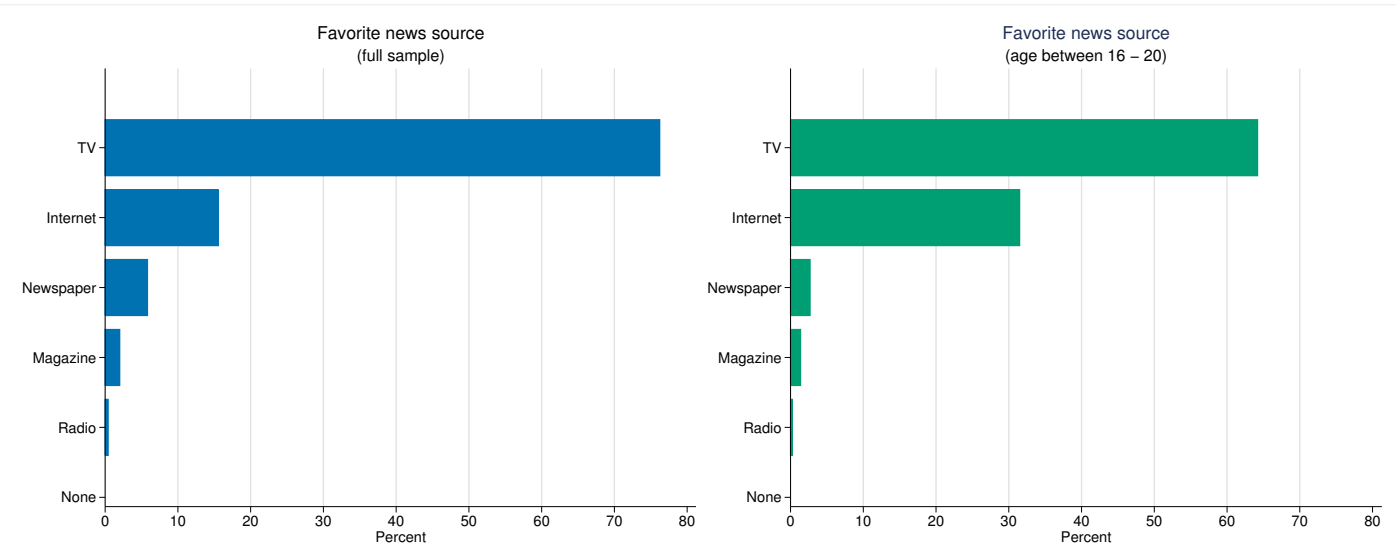

Source: Brazilian Media Survey 2015.

Owned by Globo Organization, a conglomerate founded by media mogul Roberto Marinho, Rede Globo was launched in 1965, amidst Brazil's military regime. Since then it quickly expanded to become the leading TV network in the country. According to La Ferrara et al. (2012), Rede Globo's swift growth started during the military dictatorship as a consequence of the central authority's ambition to integrate the country using mass media. The government saw in television the potential to promote a sense of national identity and, thus, encouraged its expansion. This was accomplished by subsidizing credit for set sales and by granting concessions following clientelistic and political criteria, a process from which Globo took great advantage. It has since been regarded as the most powerful television network in Brazil, with 35 affiliated networks and over 3305 retransmission stations. That enables Globo's TV signal to reach $98.56 \%$ of municipalities and $99.51 \%$ of the population. ${ }^{8}$ In a country where most people have access to television, Globo's presence in the everyday life of Brazilian citizens cannot be overstated. Kennedy and Prat (2017) call attention to the fact that, along with Dogan Media from Turkey and Atresmedia from Spain, Globo is one of the top media companies in the world in terms of power to swing an election. According to the Brazilian Electoral Study (ESEB), when asked to evaluate nine different institutions, voters placed the Catholic Church in first place and Rede Globo in second.(Porto, 2007b). ${ }^{9}$

Its flagship newscast is Jornal Nacional. On air from Monday to Saturday at 8:30 pm, it holds almost $70 \%$ of the TV share in its time slot, the equivalent to 31 million viewers, an impressive number when compared to similar news programs from Europe and North America (Mesquita, 2010a). ${ }^{10}$ According to the Brazilian Media Survey of 2015, it is also the most trusted newscast in Brazilian television, as Figure 2 shows. Note that this pattern still holds for young voters, our population of interest in this paper.

\footnotetext{
${ }^{8}$ For more information see http://comercial2.redeglobo.com.br/atlasdecobertura/Paginas/Totalizador.aspx (in Portuguese).

${ }^{9}$ Brazil is the country with the largest number o Catholics in the world.

${ }^{10}$ For the sake of comparison, Mesquita (2010a) notes that NBC Nightly News, America's most watched newscast, has an audience share of 15\%, BBC's Six O'Clock News has a share of 26\% and TF1's 20 Heures from France has $46 \%$ of the audience share.
} 
Figure 2: Trust in newscasts from major networks.
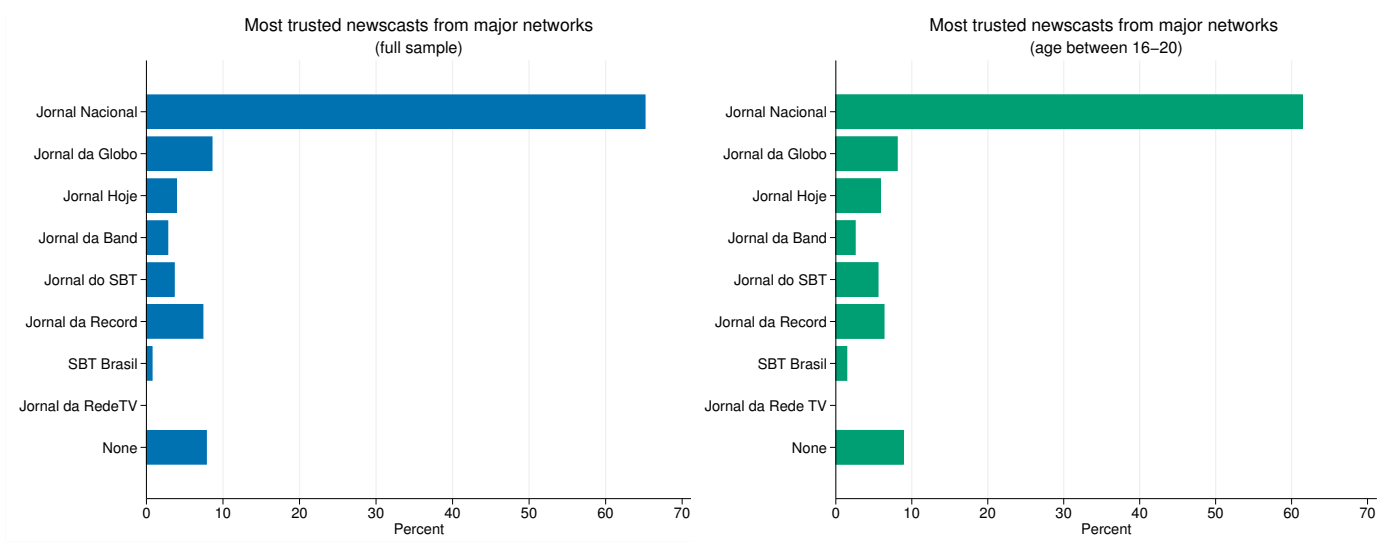

Source: Brazilian Media Survey 2015.

The consolidation of Brazilian democracy in the 90's and the many changes that happened in Rede Globo's News Division helped to shape the current format of Jornal Nacional (henceforth, "JN"). According to Porto (2007a), during the last two decades about $40 \%$ of the length of the newscast is dedicated to political, social and economic related issues. The author also argues that the newscast has greatly reduced its reliance on official sources, a sign of its departure from its authoritarian roots. Newspapers, often used as a proxy for investment in political information ${ }^{11}$, have a low readership which is characterized by a lot overlap with the audience of Jornal Nacional: $83 \%$ of individuals who read newspapers once a week also watch JN, while just $45 \%$ of those who watch Jornal Nacional say they also read newspapers (Moisés, 2010). Overall, the massive reach of Rede Globo's signal, the salience of Jornal Nacional's content and the trust individuals place on what it broadcasts makes it a relevant source of information for voters.

\section{Data and Research Design}

\subsection{Data}

Our data comes from the first two waves of the Brazilian Media Survey (BMS). This is a nationally representative survey planned jointly by the Secretariat of Social Communication of the Brazilian Presidency (SECOM) and the Brazilian Institute of Public Opinion and Statistics (IBOPE). Its first wave, the BMS 2014, was implemented between October 12 and November 6, 2013, while its second wave, the BMS 2015, was implemented between November 5 and November 22, 2014. ${ }^{12}$ A total of 36624 citizens in 848 municipalities were interviewed face-to-face about their media consumption habits. According to the official release, the main objective of this survey was to map these habits in order to improve the government's advertisement policies. The summary statistics for our main variables of interest can be found in Table 1.

\footnotetext{
${ }^{11}$ For example, Holbein and Rangel (2016) measure the impact of the Brazilian compulsory voting law on political information acquisition using newspaper as their proxy.

${ }^{12}$ Even though BMS 2016 was released on January, 2017, we do not use this data in our analysis because of two key methodological changes were implemented. First, there is no information on the month and year of birth of respondents. Second, the question used to construct our main dependent variable was removed from the survey.
} 
Table 1: Summary statistics.

\begin{tabular}{ccccccc}
\hline & Observations & Mean & Std. Dev. & Min. & Median & Max. \\
\hline \hline Panel A: TV shows & & & & & & \\
Jornal Nacional & & & & & & \\
Other newscasts & 28282 & 0.463 & 0.499 & 0 & 0 & 1 \\
Soap operas & 20380 & 0.964 & 0.186 & 0 & 1 & 1 \\
Soccer games & 27939 & 0.430 & 0.495 & 0 & 0 & 1 \\
Panel B: Baseline covariates & 26632 & 0.143 & 0.350 & 0 & 0 & 1 \\
Student & & & & & & \\
Education & 33565 & 0.063 & 0.243 & 0 & 0 & 1 \\
HH Income & 33565 & 6.526 & 2.077 & 2 & 7 & 10 \\
White & 31204 & 2.496 & 0.995 & 1 & 2 & 6 \\
Male & 33565 & 0.373 & 0.484 & 0 & 0 & 1 \\
State capital & 33565 & 0.482 & 0.500 & 0 & 0 & 1 \\
$\quad 33565$ & 0.304 & 0.460 & 0 & 0 & 1 \\
& & & & & & \\
\hline \hline
\end{tabular}

Notes: On Panel A, the variable Jornal Nacional is an indicator which takes value 1 whenever the respondent says that Jornal Nacional is one of the three TV shows that he or she watches the most during the the most during the week. The variable Other newsoasts is an incator which takes value whenever the respondent says that SBT Brasil, Jornal da Record, Jornal da Band, Jornal Hoje, Jornal da Globo, Jornal The Naite Jornal do SBT are one of the three TV shows that he or she watches the most. The variable Soccer games is an indicator which takes value 1 whenever the respondent says that soccer games broadcasted by Globo, Band or Record are one of the three TV shows that he or she watches the most. The variable Soap operas is an indicator which takes value 1 whenever the respondent says that the 7:30 pm or the 9:00 pm soap operas broadcasted by Rede Globo are one of the three TV shows that he or she watches the most. On Panel B, HH Income is the household income measured on a scale from one to six, where one stands for one minimum wage and six stands for over 20 minimum wages. Education is measured on a scale from 1 to 10 , where 1 stands for being illiterate and 10 stands for having successfully obtained a college degree. Since the compulsory voting law does not apply to illiterate citizens, this group is removed from our sample. All other variables are indicators for demographic characteristics. Sample consists of literate citizens who responded the Brazilian Media Survey at the years of 2013 and 2014.

It is also important to consider the timing of the surveys with respect to the elections. The first round of the 2012 Local Elections took place on October 7 of that same year. On this day, citizens from all the 5568 municipalities of Brazil chose their mayors, members of the city council and members of the local legislative assemblies. On 2013, the first wave of the BMS was implemented. On October 2014 the National Elections took place. Citizens attended the ballots to elect their congressmen, senators, state governors and the president. The second wave of the BMS was implemented on November 2014, just one month after the elections. The registration deadline for the 2014 elections was at October 5, 2013. Thus, by the time both surveys were implemented all the candidates running on the national race had been officially announced. The timeline in Figure 3 helps to understand how the timing of the Brazilian Media Survey relates to the local and federal elections.

Figure 3: Timing of the Brazilian Media Survey.

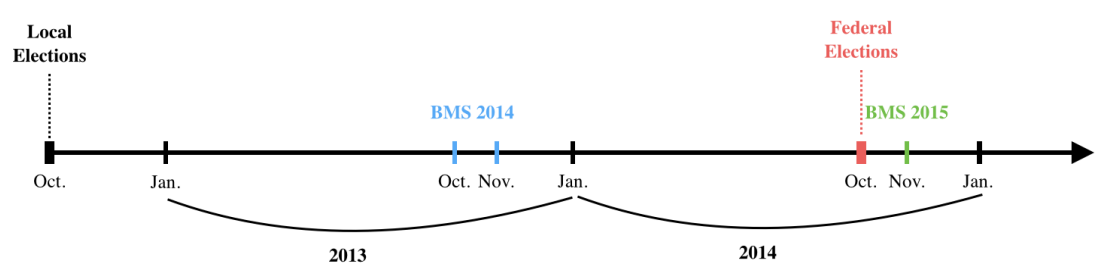

In order to assure that the sample was representative, data from the 2010 National Census and the 2011 National Household Sample Survey were used. In the first stage of the sampling procedure, municipalities were randomly selected using probability proportional to size (PPS) sampling on the population older than 16 years old. Next, within each selected municipality, census tracts were selected using PPS once again. In the last step, individuals were chosen following proportional quotas on gender, race, age, education and activity. 


\subsection{Identification Strategy}

Our aim is to evaluate the impact of the Brazilian compulsory voting law on the consumption of Jornal Nacional, Rede Globo's main newscast. We exploit the credibly exogenous source of variation of political participation which comes from the compulsory voting law in Brazil in order to provide results which can be interpreted as causal. As previously mentioned, the cost of abstention in Brazilian elections is a deterministic and discontinuous function of the age of the individual, enabling the use of a sharp regression discontinuity design (RDD) approach.

Similar to de Leon and Rizzi (2014) and Holbein and Rangel (2016), we compare individuals whose ages are in the neighborhood of the threshold that determines the change from voluntary voting to compulsory voting. Following Lee and Lemieux (2010) we run an OLS on both sides of the threshold and compare the predicted value of their dependent variable at the discontinuity. We estimate the following equation:

$$
Y_{i}=\alpha+\beta_{k} M_{i}+f\left(A_{i}-k\right)+\epsilon_{i}
$$

where $M_{i}$ is a dummy which indicates whether individual $i$ is exposed to compulsory voting $\left(M_{i}=1\right)$ or not $\left(M_{i}=0\right)$. $A_{i}$ is the age of individual $i$ in months in the elections of October $2014 . k=216$ is the age cutoff in months set by the law, and $f($.$) are continuous functions of our running variable$ centered at the cutoff value. The parameter of interest is $\beta_{k}$, the causal effect on $Y_{i}$ of being exposed to compulsory voting. We estimate our equation assuming that $f($.$) is a flexible polynomial on both sides$ of the threshold. We also take into account sampling weights in order to make the sample representative of Brazilian population. ${ }^{13}$ The running variable in our RDD setting is the centered age of the individual, represented by $A_{i}-k$, which takes negative values for individuals with $M_{i}=0$ and positive values for citizens with $M_{i}=1$. The population at the 18 th birthday cutoff is composed of those who were born at October, 1996. For those who were born in November 1996 and older, voting is mandatory. They have $A_{i}=-1$ and $M_{i}=0$. For those born in September 1996 and younger, voting is voluntary. They have $A_{i}=1$ and $M_{i}=1$. Although we leave for the supplementary appendix the estimates for those transitioning from compulsory to voluntary voting due to becoming 70 year old, the same reasoning applies. For elderly voters around the 70th birthday cutoff, those born in November 1944 will have $A_{i}=1$ and $M_{i}=1$ and those born in September 1944 will have $A_{i}=-1$ and $M_{i}=0$. We follow Gelman and Imbens (2014) and estimate only zero, first and second-degree polynomials for different bandwidths, including the optimal bandwidth calculated using the Cattaneo-Calonico-Titiunik (CCT) procedure from Calonico et al. (2014) when possible. ${ }^{14}$

We only have record of the individual's month and the year of birth, so additional care must be taken in order to reduce bias that may arise due to the few mass points of our running variable around the threshold. First, we cluster standard errors on our running variable in order to generate wider confidence intervals that reflect the imperfect fit of the parametric function away from the threshold (Lee and Card, 2008). The discreteness of our running variable also means that we have both treated and non-treated individuals at the threshold. In other words, for $A_{i}=k$, we have individuals that should have either $M_{i}=0$ or $M_{i}=1$. Assigning our observations to any of these groups may result in biased estimates of

\footnotetext{
${ }^{13}$ Although sampling used a census tract level, the most granular geographical unit by which we can identify each individual is the state they were living in at the time the survey was implemented.

${ }^{14}$ Even though optimal bandwidth selection procedures are often used in the literature, our estimates using these procedures must be taken with a grain of salt because of the discreteness of our running variable. All of these selection procedures assume that the conditional expectation is at least two times continuously differentiable, which implies the assumption that the running variable is continuously distributed. For more information, see Calonico et al. (2014).
} 
our treatment effect and so, we do not include them in our analysis.

Table 2: RDD density test for discrete running variable.

\begin{tabular}{cc}
\hline Cutoffs & p-value \\
\hline \hline 18th birthday & 0.824 \\
70th birthday & 0.393 \\
\hline
\end{tabular}

Notes: The null hypothesis is that there is no manipulation around the cutoffs. Density tests done following Frandsen (2013). Sample consists of literate citizens who responded the Brazilian Media Survey at the years of 2013 and 2014.

To identify $\beta_{k}$ as a causal parameter, our design must satisfy two key assumptions. The first is that the selection criteria for compulsory voting is not subject to manipulation. Even though it is highly improbable that the timing of births is affected by the date of the election, we follow the procedure from Frandsen (2013), which tests bunching of the running variable in a similar way to McCrary (2008), but allowing for a discrete running variable. The results in Table 2 show that we fail to reject the null hypothesis of no manipulation for both cutoffs. ${ }^{15}$

Figure 4: Covariate balance.
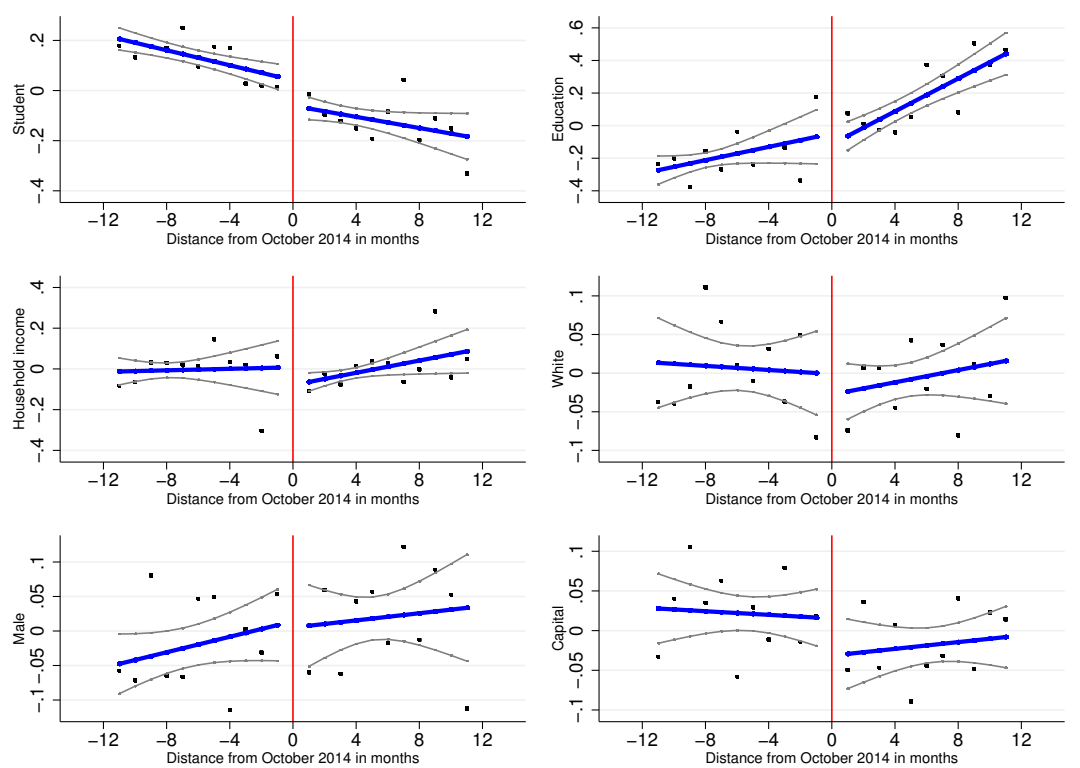

Notes: All RD plots show estimates for a linear polynomial and a 12 months bandwidth. Running variable is centered at October 2014, our true cutoff. 90\% CI are displayed.

The second assumption requires that baseline covariates do not change because of the abstention fine, i.e., there shouldn't be a treatment effect of compulsory voting on predetermined attributes of the individuals. We run our main specification from Equation 8 using as dependent variable socioeconomic characteristics that we would not expect to change as a consequence of their birthday in October, 2014, such as race, gender and household income. The results can be found in Figure 4.

Citizens past their 18th birthday in October, 2014 and for whom turnout is mandatory are displayed on the right side of 0 , while those who are 17 years and 11 months old or younger can be seen on the

\footnotetext{
${ }^{15}$ Furthermore, one can see in the histogram displayed in Figure A3 at the Appendix that the running variable is smooth around our main threshold.
} 
left side. As we should expect for predetermined variables, there is no jump around the threshold for a specification with bandwidth length of 12 months and a linear polynomial fit. ${ }^{16}$ We assess the stability of this result in Table 3, by checking how the coefficients change in statistical significance and magnitude when we change the order of the polynomials and the bandwidth length.

Table 3: Covariate balance around the 18th birthday cutoff.

\begin{tabular}{|c|c|c|c|c|c|c|c|c|}
\hline Dependent variables & $(1)$ & $(2)$ & $(3)$ & $(4)$ & $(5)$ & $(6)$ & $(7)$ & $(8)$ \\
\hline Student & $\begin{array}{l}-0.065 \\
(0.043)\end{array}$ & $\begin{array}{c}-0.108 \\
(0.033)^{* *}\end{array}$ & $\begin{array}{c}-0.220 \\
(0.043)^{* * *}\end{array}$ & $\begin{array}{c}-0.266 \\
(0.033)^{* * *}\end{array}$ & $\begin{array}{l}-0.029 \\
(0.057)\end{array}$ & $\begin{array}{c}0.024 \\
(0.040)\end{array}$ & $\begin{array}{l}-0.092 \\
(0.066)\end{array}$ & $\begin{array}{c}-0.106 \\
(0.048)^{* *}\end{array}$ \\
\hline Education & $\begin{array}{c}0.018 \\
(0.090)\end{array}$ & $\begin{array}{c}0.095 \\
(0.155)\end{array}$ & $\begin{array}{c}0.257 \\
(0.080)^{* * *}\end{array}$ & $\begin{array}{c}0.349 \\
(0.070)^{* * *}\end{array}$ & $\begin{array}{c}0.013 \\
(0.139)\end{array}$ & $\begin{array}{l}-0.357 \\
(0.276)\end{array}$ & $\begin{array}{l}-0.098 \\
(0.182)\end{array}$ & $\begin{array}{l}-0.063 \\
(0.133)\end{array}$ \\
\hline HH Income & $\begin{array}{l}-0.082 \\
(0.057)\end{array}$ & $\begin{array}{c}0.006 \\
(0.120)\end{array}$ & $\begin{array}{c}-0.040 \\
(0.048)\end{array}$ & $\begin{array}{c}0.007 \\
(0.039)\end{array}$ & $\begin{array}{c}-0.135 \\
(0.082)^{*}\end{array}$ & $\begin{array}{l}-0.167 \\
(0.243)\end{array}$ & $\begin{array}{c}-0.006 \\
(0.138)\end{array}$ & $\begin{array}{l}-0.088 \\
(0.102)\end{array}$ \\
\hline White & $\begin{array}{l}-0.027 \\
(0.031)\end{array}$ & $\begin{array}{l}-0.030 \\
(0.049)\end{array}$ & $\begin{array}{l}-0.014 \\
(0.024)\end{array}$ & $\begin{array}{l}-0.014 \\
(0.024)\end{array}$ & $\begin{array}{l}-0.010 \\
(0.054)\end{array}$ & $\begin{array}{l}-0.038 \\
(0.107)\end{array}$ & $\begin{array}{l}-0.007 \\
(0.053)\end{array}$ & $\begin{array}{l}-0.027 \\
(0.050)\end{array}$ \\
\hline Male & $\begin{array}{c}0.048 \\
(0.041)\end{array}$ & $\begin{array}{c}0.005 \\
(0.047)\end{array}$ & $\begin{array}{c}0.034 \\
(0.034)\end{array}$ & $\begin{array}{c}0.042 \\
(0.028)\end{array}$ & $\begin{array}{c}0.017 \\
(0.048)\end{array}$ & $\begin{array}{l}-0.008 \\
(0.118)\end{array}$ & $\begin{array}{l}-0.043 \\
(0.081)\end{array}$ & $\begin{array}{l}-0.009 \\
(0.056)\end{array}$ \\
\hline State capital & $\begin{array}{c}-0.047 \\
(0.023)^{* *}\end{array}$ & $\begin{array}{l}-0.062 \\
(0.036)\end{array}$ & $\begin{array}{l}-0.050 \\
(0.026)^{*}\end{array}$ & $\begin{array}{c}-0.044 \\
(0.021)^{* *}\end{array}$ & $\begin{array}{l}-0.016 \\
(0.027)\end{array}$ & $\begin{array}{c}0.021 \\
(0.076)\end{array}$ & $\begin{array}{l}-0.014 \\
(0.045)\end{array}$ & $\begin{array}{c}-0.048 \\
(0.039)\end{array}$ \\
\hline Pol. Degree & Zero & Zero & Zero & Zero & First & First & First & First \\
\hline Bandwidth & $\mathrm{CCT}$ & \pm 4 mos. & $\pm 8 \mathrm{mos}$ & \pm 12 mos. & $\mathrm{CCT}$ & \pm 4 mos. & \pm 8 mos. & \pm 12 mos. \\
\hline
\end{tabular}

This confirms that there's no causal effect of the forcing variable on baseline characteristics and, thus, that the predetermined variables are smooth around the threshold. Having satisfied these two assumptions, we have that:

$$
\beta_{k}=\lim _{A_{i} \rightarrow k^{+}} E\left(Y_{i} \mid A_{i}\right)-\lim _{A_{i} \rightarrow k^{-}} E\left(Y_{i} \mid A_{i}\right) .
$$

The causal parameter of interest $\beta_{k}$ is the average impact of compulsory voting on a random individual at the cutoff. Under both the unconfoundedness and continuity assumption, we can say that any change in outcome $Y_{i}$ at the threshold is caused by the fact that the individual is subject to the changes that reaching the cutoff age entails. Since not all individuals comply with compulsory voting law, this estimate can be interpreted as the intent-to-treat (ITT) estimate for the causal effect of CV on the dependent variable.

\section{Results}

\subsection{Effect of CV on the consumption of Jornal Nacional}

We begin our analysis by focusing on young citizens who were first exposed to the mandatory voting law. We present our main specification results for seven different bandwidth lengths (including the CCT optimal bandwidth from Calonico et al. (2014)) and three different polynomials, to ensure robustness of the results. Our largest bandwidth of choice consists of a 24 months open interval. It includes citizens who were born between October 1994 and October 1998, i.e., those who where younger than 20 and older than 16 by the time of the federal elections of October 2014. This ensures that that every individual born

\footnotetext{
${ }^{16}$ We use this same specification on all the remaining RD figures in this paper.
} 
between September 1994 and September 1996 is facing abstention penalties for the first time. Conversely, everyone with birth date between November, 1996 and September, 1998 has not yet been subject to the compulsory voting legislation.

We use the following question posed to individuals in the two waves of the Brazilian Media Survey: "What is the TV show that you watch the most during the week?" This is an open-ended question which is repeated three times in order to find the respondent's first, second and third favorite show in both cable and broadcast TV. The phrasing of the question allows us to measure the importance of Rede Globo's Jornal Nacional relative to other TV shows. We transform the answers into an indicator variable coded to take value 1 whenever Jornal Nacional is one of the respondent's three most watched TV shows. This indicator is our dependent variable. The interpretation of the coefficients that come from linear probability models is straightforward: $\beta_{k}$ is the percent change on the probability Jornal Nacional is reported as one of the individual's three most watched newscasts.

Figure 5: Impact of exposure to abstention penalties on the consumption of Jornal Nacional.
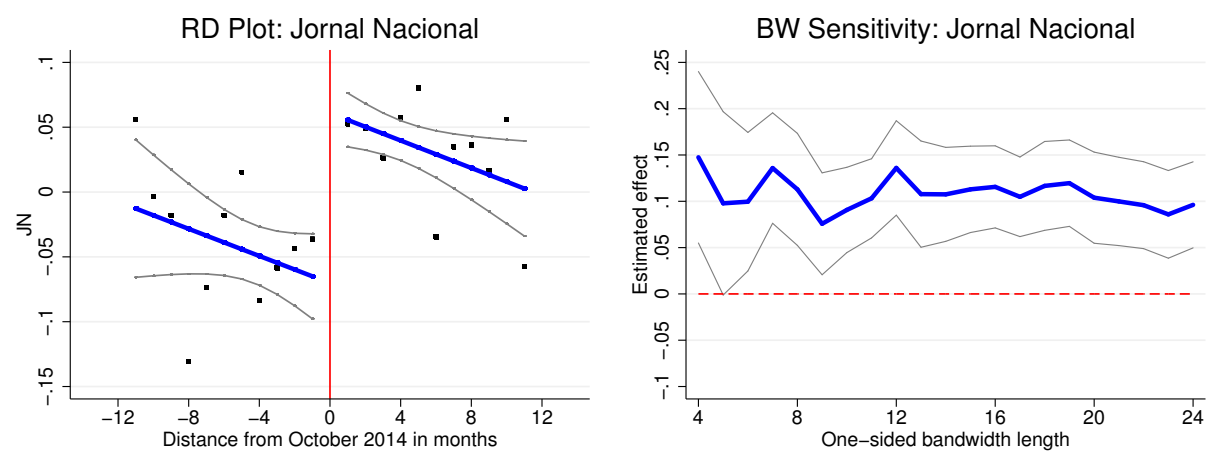

Notes: This figure displays both the treatment effect of exposure to abstention penalties on the consumption of JN and the sensitivity of our estimates to different bandwidth lengths. Running variable is centered at October 2014 , our true cutoff. Specification on the RD plot uses a linear polynomial and a 12 months bandwidth. Effects on the BW sensitivity test are estimated using a linear polynomial. $90 \%$ CI are displayed.

Our main result is illustrated in Figure 5. For our specification of choice, we see a sharp jump around the threshold. This result confirms that exposure to compulsory voting law increases the probability of watching Jornal Nacional. On the same figure we can all see that, for almost all bandwidth lengths treatment coefficients tend to stay around 0.1 and are statistically distinct from zero. Table 4 presents the estimated effects for different combinations of polynomial and bandwidth length. Column 1 provides robust RD estimates calculated using the optimal bandwidth procedure from Calonico et al. (2014) for three different polynomials. The remaining columns present the conventional RD estimates for treatment effect across different bandwidth lengths. All our specifications include year and state fixed effects in order to account for both the timing of the survey and for unobservable characteristics from each state. 
Table 4: Treatment effect of exposure to abstention penalties on the consumption of Jornal Nacional at the 18th birthday cutoff.

\begin{tabular}{|c|c|c|c|c|c|c|c|}
\hline Polynomial order & (1) & (2) & (3) & (4) & $(5)$ & (6) & (7) \\
\hline Zero & $\begin{array}{c}0.108 \\
(0.026)^{* * *}\end{array}$ & $\begin{array}{c}0.117 \\
(0.055)^{*}\end{array}$ & $\begin{array}{c}0.084 \\
(0.021)^{* * *}\end{array}$ & $\begin{array}{c}0.072 \\
(0.020)^{* * *}\end{array}$ & $\begin{array}{c}0.067 \\
(0.018)^{* * *}\end{array}$ & $\begin{array}{c}0.071 \\
(0.018)^{* * *}\end{array}$ & $\begin{array}{l}0.070 \\
0.018)^{* * *}\end{array}$ \\
\hline First & 0.117 & 0.148 & 0.113 & 0.136 & 0.116 & 0.104 & 0.096 \\
\hline Second & $\begin{array}{c}(0.031)^{* * *} \\
0.087 \\
(0.038)^{* *}\end{array}$ & $\begin{array}{c}(0.056)^{* *} \\
0.142 \\
(0.154)\end{array}$ & $\begin{array}{c}(0.037)^{* * *} \\
0.119 \\
(0.057)^{*}\end{array}$ & $\begin{array}{c}(0.031)^{* * *} \\
0.043 \\
(0.051)\end{array}$ & $\begin{array}{c}(0.027)^{* * *} \\
0.087 \\
(0.034)^{* *}\end{array}$ & $\begin{array}{c}(0.030)^{* * *} \\
0.122 \\
(0.035)^{* * *}\end{array}$ & $\begin{array}{c}(0.028)^{* * *} \\
0.115 \\
(0.032)^{* * *}\end{array}$ \\
\hline Mean D.V. for $M_{i}=0$ & - & 0.187 & 0.191 & 0.192 & 0.198 & 0.205 & 0.210 \\
\hline Observations & - & 374 & 903 & 1,377 & 1,788 & 2,155 & 2,444 \\
\hline Bandwidth & $\mathrm{CCT}$ & \pm 4 mos. & $\pm 8 \mathrm{mos}$ & \pm 12 mos. & \pm 16 mos. & \pm 20 mos. & \pm 24 mos. \\
\hline
\end{tabular}

Notes: Each figure in the table is from a separate local regression with the specified bandwidth and polynomial. The dependent variable is an indicator which takes value 1 whenever the respondent says that Jornal Nacional is one of the three TV shows that he or she watches the most during the week. Sample consists of literate citizens who responded the Brazilian Media Survey at the years of 2013 and 2014. CCT optimal bandwidths are 10.60 (zero degree poly.), 15.39 (first degree poly.) and 22.93 (second degree poly.). All standard errors are clustered on age measured in months and all regressions include state and survey year fixed-effects. Significance: ${ }^{* *} \mathrm{p}<0.01,{ }^{* *} \mathrm{p}<0.05,{ }^{*} \mathrm{p}<0.1$.

The estimated coefficient is remarkably stable, achieving significance in nineteen of the twenty one different specifications. Since our dependent variable is a dummy (i.e. our regressions are linear probability models) the interpretation of the coefficients is straightforward. A change from the voluntary voting to the mandatory voting regime increases the probability of an individual to name Jornal Nacional as one of her most watched shows in 13.6 percentage points for the linear local regression in the intermediate bandwidth of twelve months. Because the mean of our dependent variable before the cutoff is 0.192 for this bandwidth length, our causal estimate represents a $70 \%$ increase in the probability to watch Jornal Nacional. We attribute this impact to the abstention penalties the citizen becomes subject to when he or she reaches the age of eighteen. ${ }^{17}$

\section{Robustness}

Even though all baseline covariates are balanced and there's no reason to believe that any manipulation of the forcing variable took place in our sample, we must still address some possible confounding factors that may compromise our results.

First of all, it is possible that the impact we've found for young voters is not restricted to Jornal Nacional. Individuals may be watching other newscasts or might be just watching more TV. In order to check this possibility we create three different indicators which we use as dependent variables. The first one takes value 1 whenever the respondent says that one of the newscasts broadcasted by the four major TV networks in Brazil, namely Globo, SBT, Band and Record, are one of the three TV shows that he or she watches the most. The second dependent variable takes value 1 whenever the respondent says that soccer games are one of the three three TV shows that she watches the most. Finally, the third dependent variable takes value 1 whenever the respondent says that the 7:30pm or the 9:00pm soap operas broadcasted by Rede Globo are one of the three TV shows that she watches the most. Since Jornal Nacional goes on air from 8:30pm until 9:00pm, it is possible that viewers are merely watching the newscast by inertia, when what they're truly seeking to consume is entertainment.

\footnotetext{
${ }^{17}$ No effect is found for those transitioning from CV to voluntary voting at the 70th birthday cutoff. Results can be seen on Table A1.
} 
Figure 6: Impact of exposure to abstention penalties on the consumption of other TV shows.
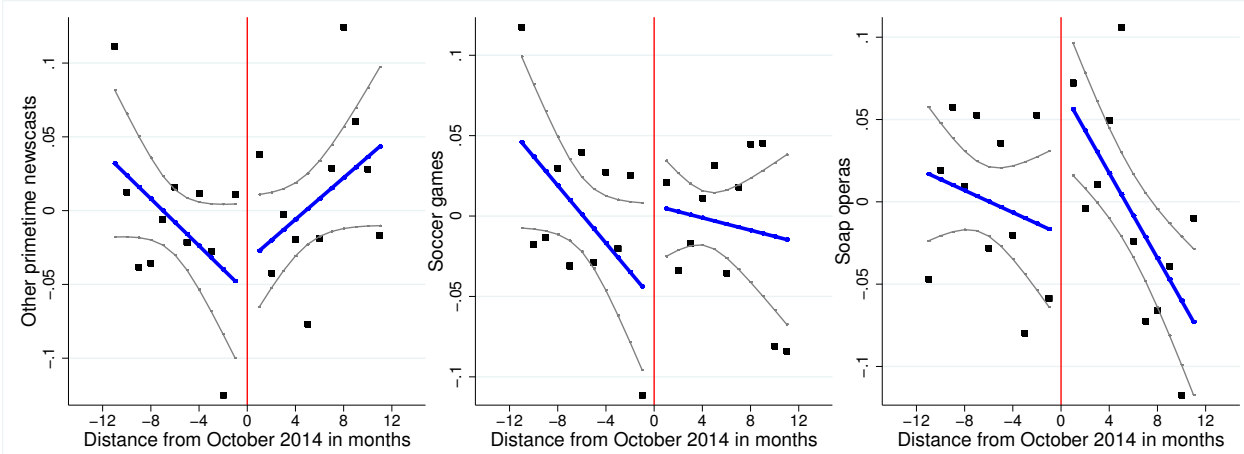

Notes: This figure displays the treatment effect of exposure to abstention penalties on the consumption of other primetime newscasts, soap operas and soccer games. Running variable is centered at October 2014, our true cutoff. Specification on the RD plots uses a linear polynomial and a 12 months bandwidth. $90 \%$ CI are displayed.

The results can be found in Figure 6 and Table 5. They support the idea that voters, when induced to attend the ballots, are using Jornal Nacional as their main source of information. This points out that voters converge to the greater reputation outlet and do not diversify the news coverage they are exposed to. No changes in the consumption of other primetime newscasts from Globo and other networks is detected. This result is coherent with the idea that JN is the most trusted newscast and, therefore, would be the one where people would try to inform themselves. Moreover, consumption of TV shows focused on entertainment such as soccer matches and soap operas is also not affected. This rules out the idea that individuals are watching JN inertially, while waiting for the 9:00pm soap opera or a soccer match to begin. Taken together, these results emphasize that the increase in consumption of JN is not coming from an increase in general broadcast programming consumption, but for a focused interest on becoming informed from the source that the agents prefer and consider to be more reliable. 
Table 5: Treatment effect of exposure to abstention penalties on the consumption of other TV shows at the 18th birthday cutoff.

\begin{tabular}{|c|c|c|c|c|c|c|c|}
\hline Polynomial order & (1) & $(2)$ & (3) & (4) & $(5)$ & (6) & $(7)$ \\
\hline \multicolumn{8}{|l|}{ Panel A: Other newscasts } \\
\hline Zero & $\begin{array}{c}0.012 \\
(0.024)\end{array}$ & $\begin{array}{c}0.038 \\
(0.055)\end{array}$ & $\begin{array}{c}0.002 \\
(0.022)\end{array}$ & $\begin{array}{c}0.010 \\
(0.024)\end{array}$ & $\begin{array}{c}0.004 \\
(0.019)\end{array}$ & $\begin{array}{c}0.008 \\
(0.016)\end{array}$ & $\begin{array}{c}0.011 \\
(0.015)\end{array}$ \\
\hline First & $\begin{array}{c}0.029 \\
(0.036)\end{array}$ & $\begin{array}{c}0.047 \\
(0.066)\end{array}$ & $\begin{array}{l}0.037 \\
(0.064)\end{array}$ & $\begin{array}{l}0.023 \\
(0.048)\end{array}$ & $\begin{array}{l}0.034 \\
(0.034)\end{array}$ & $\begin{array}{l}0.014 \\
(0.032)\end{array}$ & $\begin{array}{c}0.002 \\
(0.030)\end{array}$ \\
\hline Second & $\begin{array}{c}0.038 \\
(0.060)\end{array}$ & $\begin{array}{c}-0.102 \\
(0.074)\end{array}$ & $\begin{array}{c}0.116 \\
(0.085)\end{array}$ & $\begin{array}{l}-0.008 \\
(0.085)\end{array}$ & $\begin{array}{c}0.004 \\
(0.068)\end{array}$ & $\begin{array}{c}0.034 \\
(0.058)\end{array}$ & $\begin{array}{c}0.038 \\
(0.047)\end{array}$ \\
\hline Mean D.V. for $M_{i}=0$ & - & 0.106 & 0.111 & 0.122 & 0.121 & 0.108 & 0.099 \\
\hline Observations & - & 368 & 893 & 1,364 & 1,765 & 2,128 & 2,416 \\
\hline Bandwidth & $\mathrm{CCT}$ & \pm 4 mos. & \pm 8 mos. & \pm 12 mos. & \pm 16 mos. & $\pm 20 \mathrm{mos}$ & $\pm 24 \mathrm{mos}$ \\
\hline \multicolumn{8}{|l|}{ Panel B: Soccer games } \\
\hline Zero & $\begin{array}{c}0.014 \\
(0.024)\end{array}$ & $\begin{array}{c}0.012 \\
(0.047)\end{array}$ & $\begin{array}{c}0.013 \\
(0.022)\end{array}$ & $\begin{array}{l}-0.009 \\
(0.020)\end{array}$ & $\begin{array}{l}0.011 \\
(0.018)\end{array}$ & $\begin{array}{l}0.013 \\
(0.017)\end{array}$ & $\begin{array}{c}0.013 \\
(0.015)\end{array}$ \\
\hline First & $\begin{array}{c}0.022 \\
(0.035)\end{array}$ & 0.144 & 0.031 & 0.061 & 0.005 & 0.004 & 0.008 \\
\hline Second & $\begin{array}{c}0.041 \\
(0.050)\end{array}$ & $\begin{array}{c}0.047)^{0.453} \\
(0.121)^{* *}\end{array}$ & $\begin{array}{c}(0.063) \\
0.140 \\
(0.072)^{*}\end{array}$ & $\begin{array}{c}(0.044) \\
0.000 \\
(0.083)\end{array}$ & $\begin{array}{c}(0.037) \\
0.086 \\
(0.058)\end{array}$ & $\begin{array}{c}(0.032) \\
0.055 \\
(0.057)\end{array}$ & $\begin{array}{c}(0.029) \\
0.035 \\
(0.049)\end{array}$ \\
\hline Mean D.V. for $M_{i}=0$ & - & 0.092 & 0.113 & 0.130 & 0.123 & 0.121 & 0.118 \\
\hline Observations & - & 360 & 879 & 1,344 & 1,742 & 2,103 & 2,387 \\
\hline Bandwidth & $\mathrm{CCT}$ & \pm 4 mos. & \pm 8 mos. & \pm 12 mos. & \pm 16 mos. & \pm 20 mos. & \pm 24 mos. \\
\hline \multicolumn{8}{|l|}{ Panel C: Soap operas } \\
\hline Zero & $\begin{array}{c}0.032 \\
(0.028)\end{array}$ & $\begin{array}{c}0.069 \\
(0.050)\end{array}$ & $\begin{array}{c}0.025 \\
(0.031)\end{array}$ & $\begin{array}{c}-0.003 \\
(0.024)\end{array}$ & $\begin{array}{c}0.006 \\
(0.021)\end{array}$ & $\begin{array}{c}-0.009 \\
(0.019)\end{array}$ & $\begin{array}{l}-0.013 \\
(0.021)\end{array}$ \\
\hline First & 0.065 & $\begin{array}{l}-0.045 \\
-0.097)\end{array}$ & 0.121 & 0.091 & 0.033 & 0.048 & 0.032 \\
\hline Second & $\begin{array}{c}(0.039)^{*} \\
0.055 \\
(0.055)\end{array}$ & $\begin{array}{c}(0.097) \\
0.485 \\
(0.056)^{* * *}\end{array}$ & $\begin{array}{c}(0.067)^{*} \\
-0.034 \\
(0.108)\end{array}$ & $\begin{array}{c}(0.051)^{*} \\
0.136 \\
(0.077)^{*}\end{array}$ & $\begin{array}{c}(0.044) \\
0.162 \\
(0.069)^{* *}\end{array}$ & $\begin{array}{c}(0.036) \\
0.075 \\
(0.061)\end{array}$ & $\begin{array}{c}(0.036) \\
0.080 \\
(0.057)\end{array}$ \\
\hline Mean D.V. for $M_{i}=0$ & - & 0.430 & 0.443 & 0.450 & 0.450 & 0.452 & 0.447 \\
\hline Observations & - & 380 & 922 & 1,409 & 1,830 & 2,206 & 2,506 \\
\hline Bandwidth & $\overline{\mathrm{CCT}}$ & $\pm 4 \mathrm{mos}$ & $\pm 8 \mathrm{mos}$ & \pm 12 mos. & \pm 16 mos. & \pm 20 mos. & \pm 24 mos. \\
\hline
\end{tabular}

Notes: Each figure in the table is from a separate local regression with the specified bandwidth and polynomial. Each panel displays the results for different dependent variables. Panel A presents the results for the dependent variable as an indicator which takes value 1 whenever the respondent says that SBT Brasil, Jornal da Record, Jornal da Band, Jornal Hoje, Jornal da Globo, Jornal da Noite or Jornal do SBT are one of the three TV shows that he or she watches the most. Panel B presents the results for the dependent variable as an indicator which takes value 1 whenever the respondent says that soccer games broadcasted by Globo, Band or Record are one of the thre TV the three TV shows that he or she watches the most. Panel $C$ presents the results for the dependent variable as an indicator which takes value 1 whenever the respondent says that the 7:30 pm or the 9:00 pm soap operas broadcasted by Rede Globo are one of the three TV shows that he or she watches the most. Sample consists of literate citizens who responded the Brazilian Media Survey at the years of 2013 and 2014. For estimates in Panel A CCT optimal bandwidths are 12.69 (zero degree poly.), 16.36 (first degree poly.) and 20.67 (second degree poly.). For estimates in Panel B, CCT optimal bandwidths are 9.998 (zero degree poly.), 18.10 (first degree poly.) and 22.52 (second degree poly.). For estimates in Panel C, CCT optimal bandwidths are 8.322 (zero degree poly.), 16.65 (first degree poly.) and 21.89 (second degree poly.). All standard errors are clustered on age measured in months and all regressions include state and survey year fixed-effects. Significance: $* * * \mathrm{p}<0.01,{ }^{* *} \mathrm{p}<0.05,{ }^{*} \mathrm{p}<0.1$.

Our estimates can also be affected by the broad changes an individual faces when turning eighteen. In Brazil, eighteen is the legal adulthood. Adults are allowed to consume alcohol, to have a driver's licence and also attend the annual military draft (mandatory for male citizens). The difference of our treatment is defined by becoming eighteen at a specific month and year, not simply becoming eighteen (in any month). The other allowances are conceived regardless of the specific date of birthday. So if our results hold, we should expect no change on how voters acquire information for individual turning eighteen in different cutoffs. 
Figure 7: Treatment effect on consumption of Jornal Nacional for different thresholds.
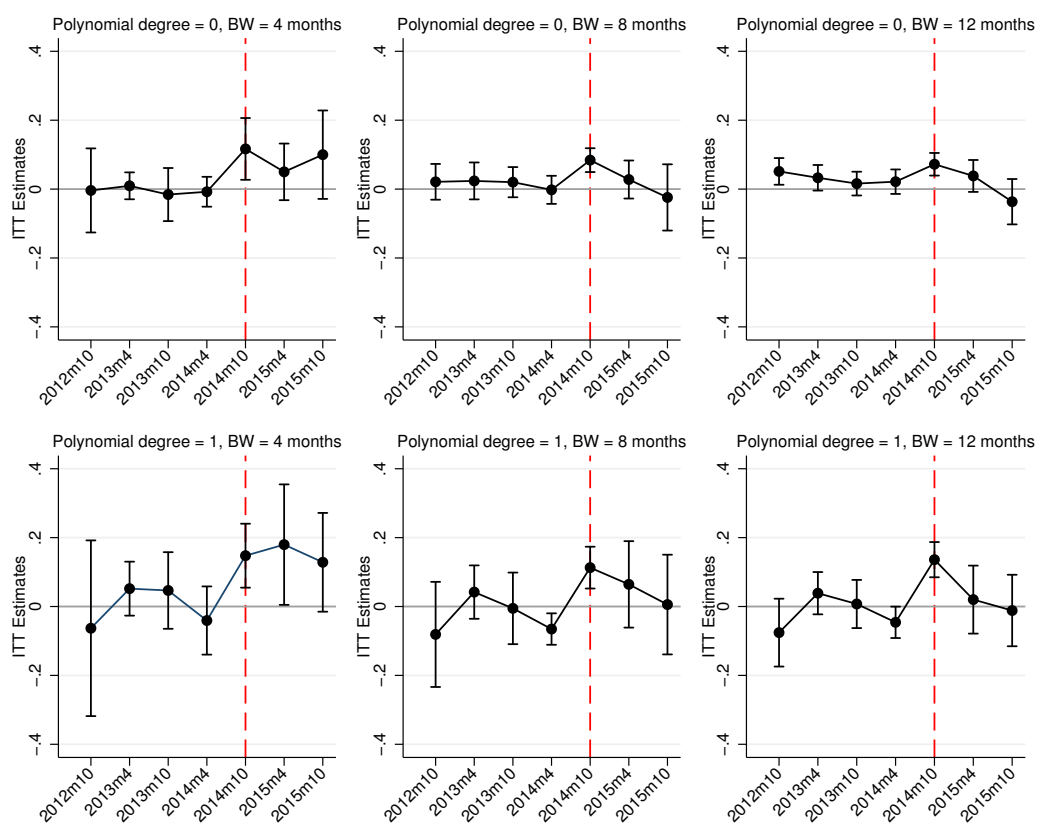

Notes: This figure displays the treatment effect estimates of exposure to abstention penalties on the consumption of Jornal Nacional for different cutoffs and different specifications. 90\% CI are displayed.

In order to test for these potential confounding factors, we first estimate the treatment effects at different placebo cutoffs for the election month. As it can be seen on Figure 7, the magnitude of our treatment estimates tends to increase as we get closer to the true cutoff at October, 2014. This suggests that our findings are not related to merely becoming eighteen, but to becoming eighteen before October, 2014 , the month of the presidential election. The point estimates can be found in Figure 6 . No robust effect is found for both zero and first degree polynomials and for different bandwidth lengths.

Table 6: Placebo tests of exposure to abstention penalties on the consumption of Jornal Nacional around the 18th birthday cutoff.

\begin{tabular}{ccccccc}
\hline False thresholds & $(1)$ & $(2)$ & $(3)$ & $(4)$ & $(5)$ & $(6)$ \\
\hline \hline & & & & & & \\
October 2012 & -0.004 & 0.021 & 0.051 & -0.063 & -0.081 & -0.076 \\
& $(0.074)$ & $(0.032)$ & $(0.024)^{* *}$ & $(0.155)$ & $(0.093)$ & $(0.060)$ \\
April 2013 & 0.009 & 0.024 & 0.033 & 0.052 & 0.042 & 0.039 \\
& $(0.024)$ & $(0.033)$ & $(0.023)$ & $(0.048)$ & $(0.047)$ & $(0.037)$ \\
October 2013 & -0.016 & 0.020 & 0.016 & 0.047 & -0.005 & 0.007 \\
& $(0.047)$ & $(0.027)$ & $(0.021)$ & $(0.068)$ & $(0.063)$ & $(0.043)$ \\
April 2014 & -0.008 & -0.012 & 0.011 & -0.041 & -0.047 & -0.053 \\
& $(0.026)$ & $(0.025)$ & $(0.023)$ & $(0.060)$ & $(0.038)$ & $(0.028)^{*}$ \\
April 2015 & 0.050 & 0.050 & 0.047 & 0.180 & 0.045 & 0.035 \\
& $(0.050)$ & $(0.038)$ & $(0.029)$ & $(0.106)$ & $(0.077)$ & $(0.060)$ \\
October 2015 & 0.100 & -0.024 & -0.037 & 0.128 & 0.006 & -0.012 \\
& $(0.078)$ & $(0.058)$ & $(0.040)$ & $(0.087)$ & $(0.088)$ & $(0.063)$ \\
Pol. Degree & Zero & Zero & Zero & First & First & First \\
Bandwidth & \pm 4 mos. & \pm 8 mos. & \pm 12 mos. & \pm 4 mos. & \pm 8 mos. & \pm 12 mos. \\
& & & & & & \\
\hline \hline
\end{tabular}

Notes: Each figure in the table is from a separate local regression with the specified bandwidth and polynomial. The dependent variable is an indicator variable which takes value 1 whenever the respondent says that Jornal Nacional is one of the three TV shows that he or she watches the most during the week. Each row presents the results for different months used as placebo cutoffs. Sample consists of literate citizens who responded the Brazilian Media Survey at the years of 2013 and 2014. All standard errors are clustered on age measured in months and all regressions include state and survey year fixed-effects. Significance: *** $\mathrm{p}<0.01,{ }^{* *} \mathrm{p}<0.05,{ }^{*} \mathrm{p}<0.1$ 
Finally, we evaluate the consumption of information for the illiterate population. They are subject to the voluntary voting regime starting from the age of sixteen, but are never under the mandatory voting rule. This means they can always register to vote, but they are never under the threat of penalties in case they abstain from the elections. In this case, the assignment mechanisms at the ages of eighteen and seventy do not apply to them and we should not expect any impact of the mandatory voting law on the consumption of Jornal Nacional. Additionally, illiterate citizens are eligible to the military and have the right buy alcohol at the age of eighteen. If it was the case that such eligibility rules have impact on the consumption of information, we should be able to detect the effect on media consumption for this population also. As we can see in Table 7, becoming eighteen has no effect for the illiterates when it comes to information acquisition through Jornal Nacional.

Table 7: Treatment effect of exposure to abstention penalties on the consumption of Jornal Nacional for illiterates.

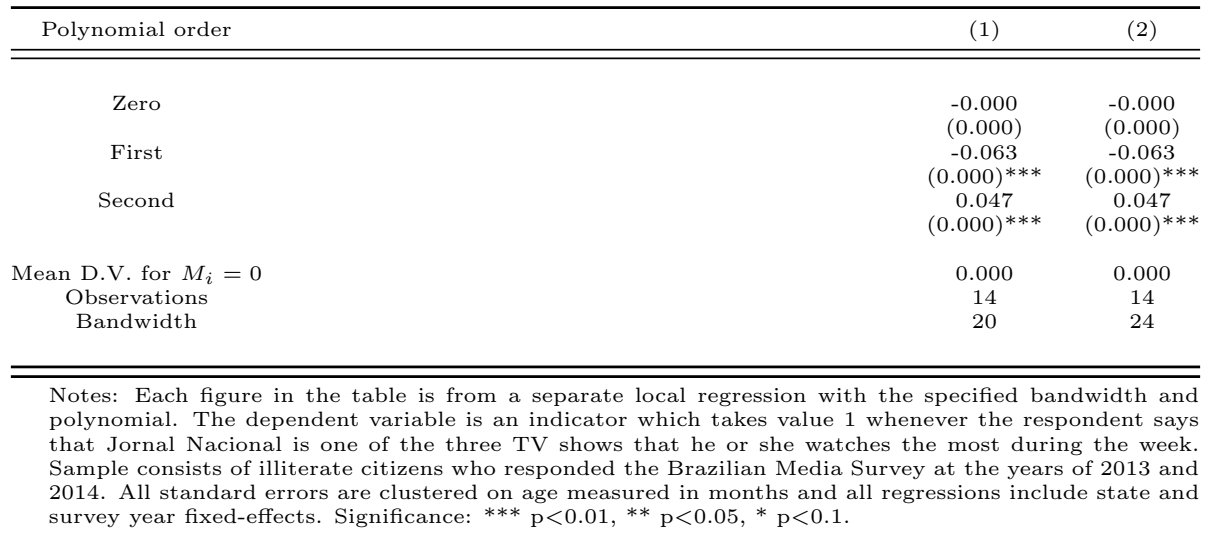

\section{Heterogeneous effects}

\subsection{Household income}

Does socioeconomic status matters when it comes to the impact of $\mathrm{CV}$ on information acquisition? As highlighted in the introduction, CV plays a key role in decreasing inequality in turnout. Because low income citizens tend to turnout less, abstention penalties would narrow the gap between rich and poor voters. Fowler (2013), for example, shows how the adoption of CV in Australia increased voter turnout among working-class citizens. Cepaluni and Hidalgo (2016), however, show that this effect may not be as straightforward as it seems. The authors find that, in Brazil, CV can increase inequality in turnout, having a larger impact on those with higher socioeconomic status.

In this section we investigate whether there is also heterogeneity by income when it comes to media consumption. The main motivation for testing if rich and poor voters are affected differently by the $\mathrm{CV}$ law is the fact that information is more costly for the second group. Acquiring a TV set, a radio or a computer represents a higher cost for poor households in terms of forgone monthly expenditure (Fava and Arends-Kuenning, 2013). They also have lower access to education and many of them live in rural areas, where TV and radio stations are more scarce and signal is more unstable due to worse infrastructure. As Kennedy and Prat (2017) highlights, socioeconomic inequality often translates into information inequality.

Poor voters are also more dependent on government programs. We can point out Bolsa Familia, 
(conditional cash transfer program), PRONAF (subsidized credit for family agriculture), and ProUni, (low interest higher education credit loans) as relevant examples. ${ }^{18}$ This greater reliance on public services imply that federal elections can be a high-stakes situation for those who are more vulnerable and thus, something they might want to inform themselves about. ${ }^{19}$

Furthermore, Power (2009) argues, the decisions to obtain and to keep a voter registration up-to-date in Brazil depends on whether the individual will need to interact with the authorities in the future in order to obtain desirable benefits and services. It is important to remember that a voter registration may be required in a number of situations such as obtaining a new ID or renewing it if the individual is over eighteen, or getting access to credit from government programs such as PRONAF or ProUni, for example. It is also one of the documents which can be used to enroll in Bolsa Familia. At the same time, failing to vote can affect services such as obtaining a passport and getting a job in the public sector, both more relevant to individuals with higher socioeconomic status. It is not immediately clear, therefore, if low and high income voters will have their information consumption affected differently as a consequence of the CV law.

Figure 8: Household income heterogeneous effects.
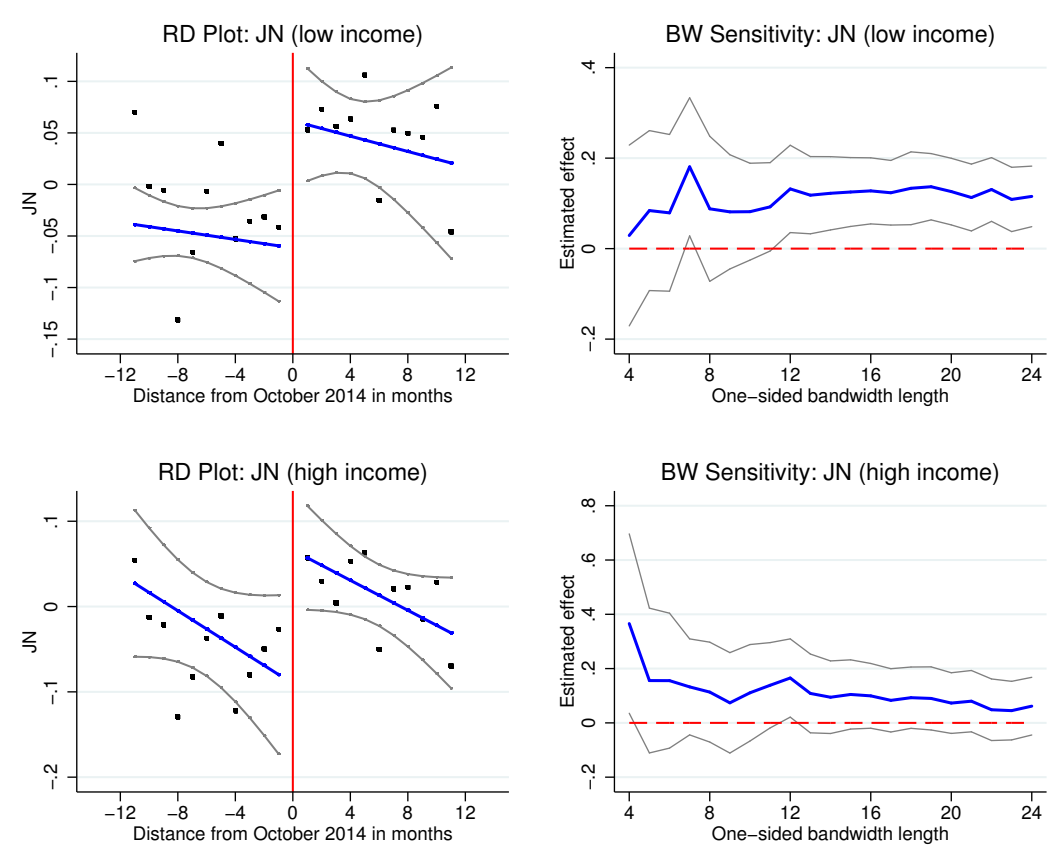

Notes: This figure displays both the treatment effect of exposure to abstention penalties on the
consumption of JN and the sensitivity of our estimates to different bandwidth lengths for those
above and below the median income. Running variable is centered at October 2014 , our true cutoff.
Specification on the RD plots uses a linear polynomial and a 12 months bandwidth. Effects on the
BW sensitivity tests are estimated using a linear polynomial. $90 \%$ CI are displayed.

In order to analyze the heterogeneous impact of $\mathrm{CV}$ on information acquisition, we split our sample between those above and below the median household income and run our main specification for each group. The results are displayed on Figure 8. For our main specification, poor individuals are not

\footnotetext{
${ }^{18}$ In Brazil, while the majority of the students on public schools are from poorer backgrounds, the student body of public universities is comprised mostly of individuals from middle or upper-middle class households.

${ }^{19}$ This is often explored during campaigns in order to gather support. For instance, amidst the presidential election campaign of 2014 the incumbent presidential candidate Dilma Rousseff announced during a PT rally that Bolsa Família may end if her party lost the elections. For more information, see: http://g1.globo.com/sao-paulo/eleicoes/2014/noticia/2014/09/dilma-diz-que-bolsa-familia-vai-acabar-se-adversariosforem-eleitos.html (In Portuguese).
} 
differently affected by CV when compared to rich ones. On the same figure we show how treatment coefficients are stable across different bandwidth lengths for the linear specification. The BW sensitivity check shows that the statistical significance of the effect for poor voters is more robust to the inclusion of additional months. Table 8 displays the values of the coefficients for a number of polynomial and bandwidth lengths combinations, where Panel A and Panel B display, respectively, the results for low and high income citizens. The size of the impact using our main specification is 0.132 percentage points for the poor, and 0.165 for the rich. Despite the small difference in magnitude, the impact is robust only for poor voters. ${ }^{20}$

Table 8: Heterogeneous treatment effect of exposure to abstention penalties on the consumption of Jornal Nacional at the 18th birthday cutoff.

\begin{tabular}{|c|c|c|c|c|c|c|c|}
\hline Polynomial order & (1) & (2) & (3) & (4) & (5) & (6) & (7) \\
\hline \multicolumn{8}{|l|}{ Panel A: Low income } \\
\hline Zero & $\begin{array}{c}0.081 \\
(0.031)^{* * *}\end{array}$ & $\begin{array}{c}0.112 \\
(0.065)\end{array}$ & $\begin{array}{c}0.114 \\
(0.038)^{* * *}\end{array}$ & $\begin{array}{c}0.097 \\
(0.029)^{* * *}\end{array}$ & $\begin{array}{c}0.083 \\
(0.024)^{* * *}\end{array}$ & $\begin{array}{c}0.075 \\
(0.022)^{* * *}\end{array}$ & $\begin{array}{c}0.073 \\
(0.022)^{* * *}\end{array}$ \\
\hline First & 0.123 & 0.029 & 0.088 & 0.132 & 0.128 & 0.126 & 0.115 \\
\hline & $(0.040)^{* * *}$ & $(0.122)$ & $(0.098)$ & $(0.059)^{* *}$ & $(0.045)^{* * *}$ & $(0.045)^{* * *}$ & $(0.041)^{* * *}$ \\
\hline Second & $\begin{array}{c}0.097 \\
(0.048)^{* *}\end{array}$ & $\begin{array}{c}-0.464 \\
(0.127)^{* *}\end{array}$ & $\begin{array}{c}0.169 \\
(0.168)\end{array}$ & $\begin{array}{c}0.035 \\
(0.106)\end{array}$ & $\begin{array}{c}0.064 \\
(0.076)\end{array}$ & $\begin{array}{c}0.114 \\
(0.063)^{*}\end{array}$ & $\begin{array}{c}0.123 \\
(0.056)^{* *}\end{array}$ \\
\hline Mean D.V. for $M_{i}=0$ & - & 0.194 & 0.190 & 0.182 & 0.184 & 0.193 & 0.195 \\
\hline Observations & - & 232 & 521 & 788 & 1,024 & 1,236 & 1,391 \\
\hline Bandwidth & $\mathrm{CCT}$ & \pm 4 mos. & \pm 8 mos. & \pm 12 mos. & \pm 16 mos. & \pm 20 mos. & \pm 24 mos. \\
\hline \multicolumn{8}{|l|}{ Panel B: High income } \\
\hline \multirow[t]{2}{*}{ Zero } & 0.062 & 0.128 & 0.068 & 0.042 & 0.043 & 0.060 & 0.066 \\
\hline & $(0.052)$ & $(0.099)$ & $(0.061)$ & $(0.045)$ & $(0.038)$ & $(0.035)^{*}$ & $(0.035)^{*}$ \\
\hline \multirow[t]{2}{*}{ First } & 0.127 & 0.366 & 0.113 & 0.165 & 0.100 & 0.073 & 0.062 \\
\hline & $(0.068)^{*}$ & $(0.201)$ & $(0.112)$ & $(0.088) *$ & $(0.073)$ & $(0.068)$ & $(0.065)$ \\
\hline \multirow[t]{2}{*}{ Second } & 0.045 & 1.572 & 0.136 & 0.070 & 0.101 & 0.146 & 0.108 \\
\hline & $(0.081)$ & $(0.598)^{* *}$ & $(0.187)$ & $(0.132)$ & $(0.107)$ & $(0.093)$ & $(0.089)$ \\
\hline Mean D.V. for $M_{i}=0$ & - & 0.176 & 0.190 & 0.202 & 0.213 & 0.216 & 0.224 \\
\hline Observations & - & 142 & 382 & 589 & 764 & 919 & 1,053 \\
\hline Bandwidth & $\mathrm{CCT}$ & \pm 4 mos. & \pm 8 mos. & \pm 12 mos. & \pm 16 mos. & \pm 20 mos. & \pm 24 mos. \\
\hline
\end{tabular}

Notes: Each figure in the table is from a separate local regression with the specified bandwidth and polynomial. The dependent variable is an indicator which takes value 1 whenever the respondent says that Jornal Nacional is one of the three TV shows that he or she watches the most during the week. Sample consists of literate citizens who responded the Brazilian Media Survey at the years of 2013 and 2014. he median household income is two minimum wages. Panel A contains the ITT estimates for the subpopulation with income below or equal to the median. Panel B contains the ITT contains the estimates for the subpopulation with income above the CCT optimal bandwidths are 13.77 ( are clustered on age measured in months and all regressions include state and survey year fixed-effects. Significance: are clustered on age measured in
$* * * \mathrm{p}<0.01, * * \mathrm{p}<0.05, * \mathrm{p}<0.1$.

Our results suggest that compulsory voting affects the demand for information from poor and rich young voters heterogeneously. By nudging poorer citizens into becoming more informed, CV laws can play a key role in bridging the informational gap between groups that may have different underlying preferences over key policy issues such as taxation schedules and social welfare.

\subsection{Polarization}

As we have seen, CV induces more information consumption. Does it also induce media consumption in a different way for those who have a moderate opinion compared to those who evaluate the incumbent government in a positive or negative way?

\footnotetext{
${ }^{20}$ Once again, no impact is found for older citizens at the second cutoff. For both subsamples, we fail to reject the null of no effect. Results can be found on Table A2.
} 
One immediate implication of Proposition 1 is that the introduction of abstention penalties changes the composition of the electorate. Those who are moderate may become more partisan in response to the introduction of CV. Those who are less polarized and would not turnout or invest in information acquisition change their behavior when $\mathrm{CV}$ is introduced. They may start investing in information and turning out to vote.

In other words, those who already made up their minds and have strong opinions about the current state of affairs are less likely to have an interest in a new piece of evidence. They believe they already have all the information necessary to cast their vote. Moderate individuals, who are unsure about the platforms the candidates are running on, will invest in becoming more informed in order to avoid voting for the "wrong" candidate. This argument is similar to the one made by Zaller (1992). In his seminal work, the author argues that individuals with more polarized attitudes are less likely to change their opinions because they already possess information that can be at odds with new pieces of evidence and can, therefore, neutralize them.

The existing evidence suggests that there are heterogeneous effects of CV on the decision to turnout, depending on how ideologically moderate the individual is. Recent research by Shineman (2017) shows how pre-existing attitudes mediate the effect of changes in the cost of voting. The author finds that increasing the cost of participation deters participation from moderate voters more than extremist ones. León (2017) finds that moderate voters are more responsive to reductions in the cost of voting than extreme ones. Other authors find that CV impacts the level of polarization. For example, de Leon and Rizzi (2016) find that CV increases ideological extremism on a left-right spectrum and individuals' capacity to identify with political parties.

We investigate two effects related to attitude polarization and compulsory voting. First, we examine if exposure to the abstention penalties affects polarization itself. Second, if moderate individuals are affected differently by CV compared to extremists when it comes to media consumption. Polarization is measured using one of the questions of the Brazilian Media Survey, which asks the respondent to evaluate the government of the incumbent President. Answers can be "Awful", "Bad", "Regular", "Good", "Excellent" and "Don't know". We split the sample in two groups with roughly the same size based on these answers. Those who answer either "Regular" or "Don't know" are considered to have neutral evaluations. Those who consider the incumbent government "Awful", "Bad", "Good" or "Excellent" are considered polarized. Although this is not a measure of ideology, it does capture polarization to some extent, at least with respect to the incumbent government who was running for reelection in $2014 .^{21}$

\footnotetext{
${ }^{21}$ Brazil lacks a clear political cleavage that allows voters to consistently sort into the left or right of the political spectrum. Several factors contribute to this. Mainwaring et al. (1995) points that cleavages such as class, ethnicity, religion, or region never provided a basis for party competition. Current electoral rules also induce the proliferation of different political parties, making it hard for voters to understand where each party stands on different issues, and inducing individualistic behavior from the candidates during their campaigns (Mainwaring, 1999). These elements induce more personalistic than ideological voting. Furthermore, Zucco Jr and Lauderdale (2011) find that the only relevant division in the Brazilian congress is between government and opposition, not between left and right wing parties.
} 
Figure 9: Impact of exposure to penalties on government evaluation.
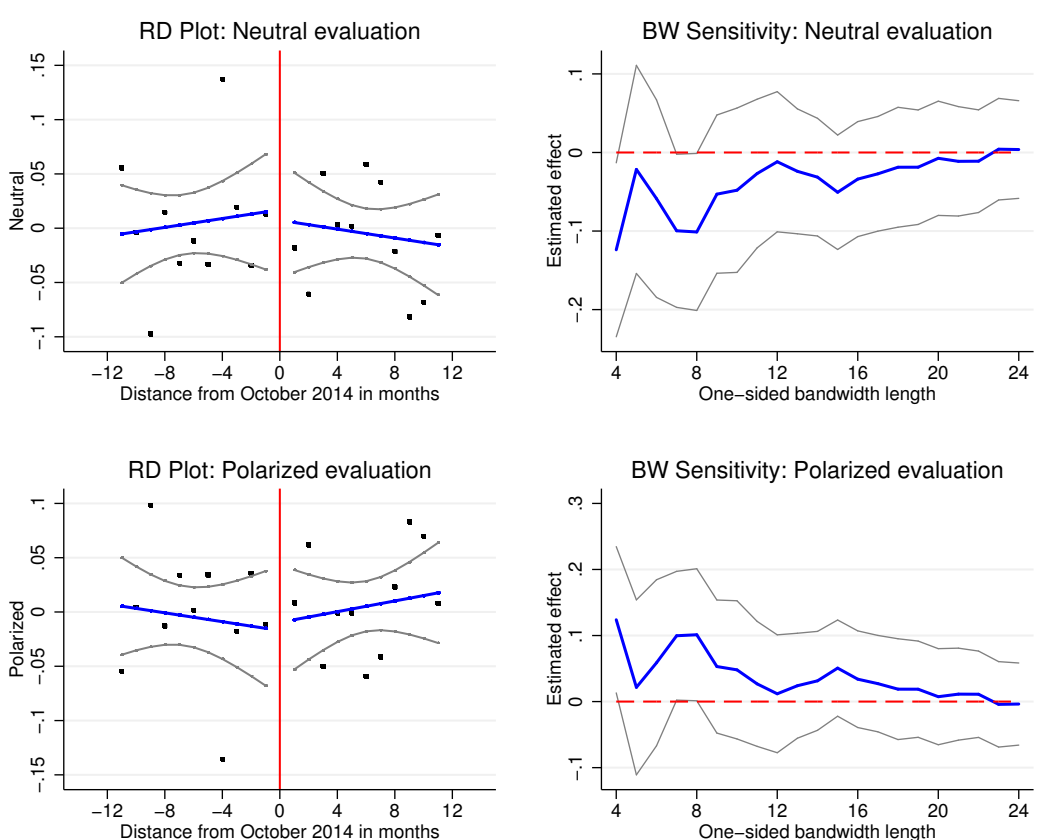

\begin{abstract}
Notes: This figure displays both the treatment effect of exposure to abstention penalties on government evaluation and the sensitivity of our estimates to different bandwidth lengths. Neutral individuals are those who don't know how to evaluate the government or classify it as "Regular". Polarized individuals are those who classify the government in either a positive or negative way. Running variable is centered at October 2014, our true cutoff. Specification on the RD plots uses a linear polynomial and a 12 months bandwidth. Effects on the BW sensitivity tests are estimated using a linear polynomial. $90 \%$ CI are displayed.
\end{abstract}

We start our analysis by investigating if the composition of the electorate is changed, as predicted by our theoretical result. As it can be seen in Figure 9, we do not find a significant change in the composition of the electorate. The bandwidth sensitivity check shows that the impact converges to zero as more months are included in the bandwidth. Overall, no significant change is found in the composition of the electorate. A closer examination of the results in Table 9 shows that this is consistent for different specifications. Even though there's no significant effect, the signals of most of the coefficients match what is predicted in our model: there's a decrease in the number of moderate individuals and an increase in those with polarized attitudes as a consequence of $\mathrm{CV}$. 
Table 9: Treatment effect of exposure to abstention penalties on government evaluation at the 18th birthday cutoff.

\begin{tabular}{|c|c|c|c|c|c|c|c|}
\hline Polynomial order & (1) & $(2)$ & (3) & (4) & (5) & (6) & (7) \\
\hline \multicolumn{8}{|l|}{$D V=$ Neutral (dummy) } \\
\hline Zero & -0.020 & -0.013 & 0.006 & -0.006 & 0.013 & 0.006 & 0.004 \\
\hline First & -0.042 & -0.124 & -0.101 & -0.012 & -0.034 & -0.007 & 0.004 \\
\hline & $(0.036)$ & $(0.068)$ & $(0.061)$ & $(0.054)$ & $(0.045)$ & $(0.044)$ & $(0.038)$ \\
\hline Second & -0.017 & -0.053 & -0.036 & -0.126 & -0.041 & -0.058 & -0.045 \\
\hline & $(0.047)$ & $(0.035)$ & $(0.093)$ & $(0.069)^{*}$ & $(0.062)$ & $(0.059)$ & $(0.055)$ \\
\hline Mean D.V. for $M_{i}=0$ & - & 0.490 & 0.497 & 0.497 & 0.494 & 0.491 & 0.493 \\
\hline Observations & - & 475 & 1,170 & 1,764 & 2,272 & 2,713 & 3,071 \\
\hline Bandwidth & $\mathrm{CCT}$ & $\pm 4 \mathrm{mos}$ & $\pm 8 \mathrm{mos}$ & \pm 12 mos. & \pm 16 mos. & \pm 20 mos. & $\pm 24 \mathrm{mos}$ \\
\hline \multicolumn{8}{|l|}{$D V=$ Polarized (dummy) } \\
\hline \multirow[t]{2}{*}{ Zero } & 0.018 & 0.013 & -0.006 & 0.006 & -0.013 & -0.006 & -0.004 \\
\hline & $(0.025)$ & $(0.054)$ & $(0.034)$ & $(0.026)$ & $(0.022)$ & $(0.020)$ & $(0.019)$ \\
\hline \multirow[t]{2}{*}{ First } & 0.045 & 0.124 & 0.101 & 0.012 & 0.034 & 0.007 & -0.004 \\
\hline & $(0.035)$ & $(0.068)$ & $(0.061)$ & $(0.054)$ & $(0.045)$ & $(0.044)$ & $(0.038)$ \\
\hline Second & $\begin{array}{c}0.013 \\
(0.050)\end{array}$ & $\begin{array}{c}0.053 \\
(0.035)\end{array}$ & $\begin{array}{c}0.036 \\
(0.093)\end{array}$ & $\begin{array}{c}0.126 \\
(0.069)^{*}\end{array}$ & $\begin{array}{c}0.041 \\
(0.062)\end{array}$ & $\begin{array}{c}0.058 \\
(0.059)\end{array}$ & $\begin{array}{c}0.045 \\
(0.055)\end{array}$ \\
\hline Mean D.V. for $M_{i}=0$ & - & 0.510 & 0.503 & 0.502 & 0.506 & 0.509 & 0.507 \\
\hline Observations & - & 475 & 1,170 & 1,764 & 2,272 & 2,713 & 3,071 \\
\hline Bandwidth & $\mathrm{CCT}$ & $\pm 4 \mathrm{mos}$ & $\pm 8 \mathrm{mos}$ & $\pm 12 \mathrm{mos}$ & $\pm 16 \mathrm{mos}$ & $\pm 20 \mathrm{mos}$ & $\pm 24 \mathrm{mos}$ \\
\hline
\end{tabular}

Notes: Each figure in the table is from a separate local regression with the specified bandwidth and polynomial. The dependent variable is an indicator which takes value 1 whenever the respondent says that Jornal Nacional is one of the three TV shows that he or she watches the most during the week. Sample consists of literate citizens who responded the Brazilian Media Survey at the years of 2013 and 2014. For estimates in Panel A, CCT who responded the Brazilian Media Survey at the years of 2013 and 2014. For estimates in Panel A, CCT For estimates in Panel B, CCT optimal bandwidths are 11.85 (zero degree poly.), 17.07 (first degree poly.) and For estimates in Panel B, CCT optimal bandwidths are 11.85 (zero degree poly.), 17.07 (first degree poly.) and
20.93 (second degree poly.). All regressions include as control variables the baseline covariates presented on 20.93 (second degree poly.). All regressions include as control variables the baseline covariates presented on
Table 1, Panel B. Standard errors are clustered on age measured in months and regressions include state and survey year fixed-effects. Significance: ${ }^{* *} \mathrm{p}<0.01,{ }^{* *} \mathrm{p}<0.05,{ }^{*} \mathrm{p}<0.1$.

A more subtle prediction we test is that more moderate voters will try to acquire information, while those who are more opinionated will not, when exposed to CV. In order to do this, we run our main specification, assessing the impact of CV on media consumption, separately for our two subsamples. In Figure 10 we see that our theoretical prediction is true for our data. Those who classify the incumbent government as "Regular" or don't know how to evaluate it present a significant increase in the demand for Jornal Nacional, while those who have positive or negative impressions of the administration do not change their behavior. The results for zero, first and second degree polynomials can be seen on Table 10. On Panel A we display the results for the moderate individuals. For our main specification using a linear polynomial and a twelve months bandwidth, we find a 0.203 percentage points. Since the mean of Jornal Nacional consumption for those who are not subject to CV is 0.193 this represents an impact of more than $100 \%$ which can be attributed to exposure to the abstention fines. On Panel B, where the results for more polarized individuals is shown, we find no significant effect of $\mathrm{CV}$ on the consumption of Jornal Nacional. 
Figure 10: Evaluation heterogeneous effects.
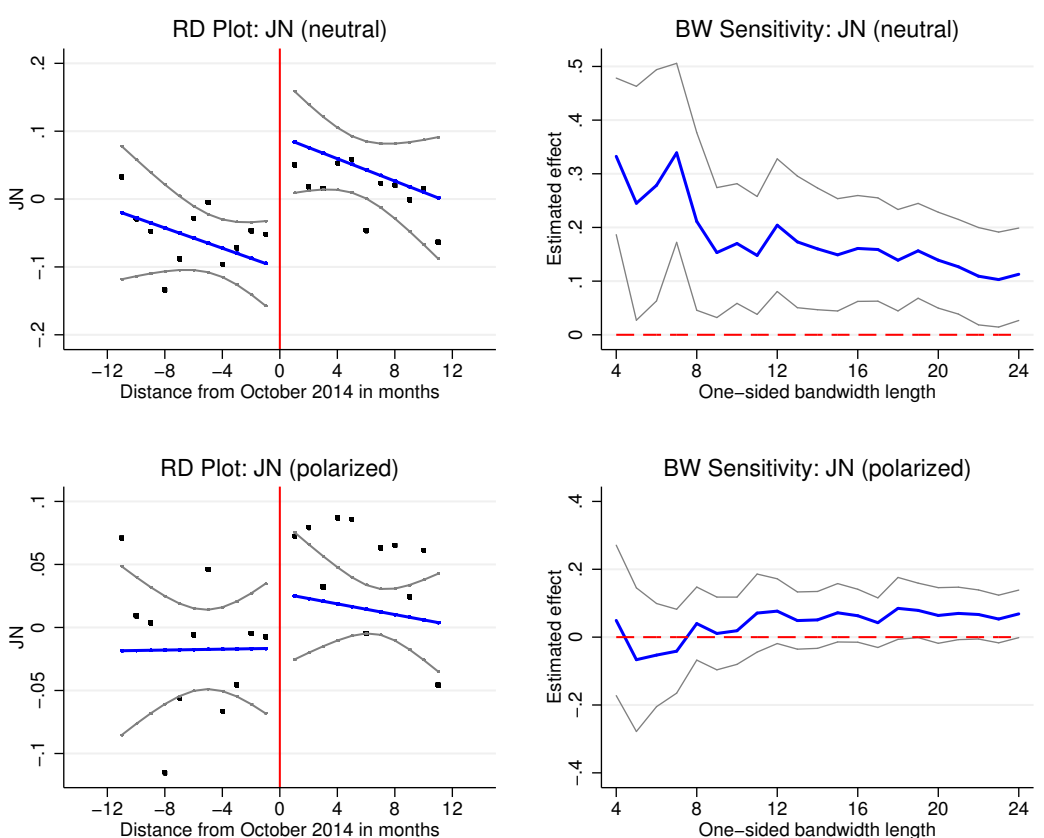

\begin{abstract}
Notes: This figure displays both the treatment effect of exposure to abstention penalties on consumption of JN and the sensitivity of our estimates to different bandwidth lengths, for those who have neutral or polarized opinions on the incumbent federal government. Neutral individuals are those who don't know how to evaluate the government or classify it as "Regular". Polarized individuals are those who classify the government in either a positive or negative way. Running variable is centered at October 2014, our true cutoff. Specification on the RD plots uses a linear polynomial and a 12 months bandwidth. Effects on the BW sensitivity tests are estimated using a linear polynomial. $90 \%$ CI are displayed.
\end{abstract}

These results show that, in spite of not changing the composition of the electorate, the impact of compulsory voting is mediated through young voters' attitudes. Those who present more moderate opinions have a higher probability to demand more information than those who are more polarized with respect to the incumbent government. This result is in line with our theoretical prediction that $\mathrm{CV}$ would change the consumption of information only of those who are less polarized. ${ }^{22}$

\footnotetext{
${ }^{22}$ For those at the second cutoff who are transitioning back to the voluntary voting regime, we find no effect on both the composition of the electorate and the differential consumption of media. For these results see Tables A3 and A4.
} 
Table 10: Government evaluation heterogeneous treatment effect of exposure to abstention penalties on the consumption of Jornal Nacional at the 18th birthday cutoff.

\begin{tabular}{|c|c|c|c|c|c|c|c|}
\hline Polynomial order & (1) & (2) & (3) & (4) & (5) & (6) & (7) \\
\hline \multicolumn{8}{|l|}{ Panel A: Neutral } \\
\hline $\begin{array}{l}\text { Zero } \\
\text { First } \\
\text { Second }\end{array}$ & $\begin{array}{c}0.089 \\
(0.039)^{* *} \\
0.111 \\
(0.050)^{* *} \\
0.096 \\
(0.065)\end{array}$ & $\begin{array}{c}0.224 \\
(0.064)^{* *} \\
0.290 \\
(0.078)^{* *} \\
0.591 \\
(0.177)^{* *}\end{array}$ & $\begin{array}{c}0.119 \\
(0.051)^{* *} \\
0.183 \\
(0.089)^{*} \\
0.361 \\
(0.164)^{* *}\end{array}$ & $\begin{array}{c}0.110 \\
(0.041)^{* *} \\
0.203 \\
(0.071)^{* * *} \\
0.130 \\
(0.125)\end{array}$ & $\begin{array}{c}0.099 \\
(0.035)^{* * *} \\
0.165 \\
(0.057)^{* * *} \\
0.149 \\
(0.084)^{*}\end{array}$ & $\begin{array}{c}0.098 \\
(0.032)^{* * *} \\
0.143 \\
(0.052)^{* * *} \\
0.177 \\
(0.069)^{* *}\end{array}$ & $\begin{array}{c}0.108 \\
(0.029)^{* * *} \\
0.111 \\
(0.051)^{* *} \\
0.184 \\
(0.063)^{* * *}\end{array}$ \\
\hline $\begin{array}{c}\text { Mean D.V. for } M_{i}=0 \\
\text { Observations } \\
\text { Bandwidth }\end{array}$ & $\begin{array}{c}- \\
\overline{\mathrm{CCT}}\end{array}$ & $\begin{array}{c}0.154 \\
198 \\
\pm 4 \mathrm{mos}\end{array}$ & $\begin{array}{l}0.191 \\
472 \\
\pm 8 \text { mos. }\end{array}$ & $\begin{array}{c}0.193 \\
\quad 695 \\
\pm 12 \mathrm{mos}\end{array}$ & $\begin{array}{l}0.196 \\
905 \\
\pm 16 \text { mos. }\end{array}$ & $\begin{array}{c}0.200 \\
1,080 \\
\pm 20 \mathrm{mos}\end{array}$ & $\begin{aligned} & 0.196 \\
& 1,217 \\
& \pm 24 \text { mos. }\end{aligned}$ \\
\hline \multicolumn{8}{|l|}{ Panel B: Polarized } \\
\hline Zero & $\begin{array}{c}0.025 \\
(0.036)\end{array}$ & $\begin{array}{l}-0.007 \\
(0.052)\end{array}$ & $\begin{array}{c}0.034 \\
(0.036)\end{array}$ & $\begin{array}{c}0.034 \\
(0.026)\end{array}$ & $\begin{array}{c}0.031 \\
(0.025)\end{array}$ & $\begin{array}{c}0.036 \\
(0.026)\end{array}$ & $\begin{array}{c}0.030 \\
(0.025)\end{array}$ \\
\hline First & $\begin{array}{c}0.071 \\
(0.063)\end{array}$ & $\begin{array}{l}-0.005 \\
(0.089)\end{array}$ & $\begin{array}{c}0.009 \\
(0.070)\end{array}$ & $\begin{array}{c}0.045 \\
(0.055)\end{array}$ & $\begin{array}{c}0.052 \\
(0.051)\end{array}$ & $\begin{array}{c}0.053 \\
(0.050)\end{array}$ & $\begin{array}{c}0.061 \\
(0.044)\end{array}$ \\
\hline Second & $\begin{array}{l}-0.039 \\
(0.074)\end{array}$ & $\begin{array}{l}-0.206 \\
(0.235)\end{array}$ & $\begin{array}{l}-0.168 \\
(0.114)\end{array}$ & $\begin{array}{l}-0.069 \\
(0.102)\end{array}$ & $\begin{array}{l}-0.017 \\
(0.082)\end{array}$ & $\begin{array}{c}0.044 \\
(0.076)\end{array}$ & $\begin{array}{c}0.028 \\
(0.066)\end{array}$ \\
\hline $\begin{array}{c}\text { Mean D.V. for } M_{i}=0 \\
\text { Observations } \\
\text { Bandwidth }\end{array}$ & $\begin{array}{c}- \\
\overline{\mathrm{CCT}}\end{array}$ & $\begin{array}{c}0.222 \\
175 \\
\pm 4 \mathrm{mos}\end{array}$ & $\begin{array}{c}0.190 \\
430 \\
\pm 8 \text { mos. }\end{array}$ & $\begin{array}{c}0.192 \\
\quad 681 \\
\pm 12 \mathrm{mos}\end{array}$ & $\begin{array}{c}0.201 \\
881 \\
\pm 16 \text { mos. }\end{array}$ & $\begin{array}{c}0.209 \\
1,071 \\
\pm 20 \text { mos. }\end{array}$ & $\begin{array}{c}0.219 \\
1,222 \\
\pm 24 \text { mos. }\end{array}$ \\
\hline
\end{tabular}

Notes: Each figure in the table is from a separate local regression with the specified bandwidth and polynomial. The dependent variable is an indicator which takes value 1 whenever the respondent says that Jornal Nacional is one of the three TV shows that he or she watches the most during the week. Sample consists of literate citizens who responded the Brazilian Media Survey at the years of 2013 and 2014. For estimates in Panel A, CCT optimal bandwidths are the Brazilian Media Survey at the years of 2013 and 2014. For estimates in Panel A, CCT optimal bandwidths are
17.93 (zero degree poly.), 23.58 (first degree poly.) and 25.29 (second degree poly.). For estimates in Panel B, CCT optimal bandwidths are 11.54 (zero degree poly.), 17.74 (first degree poly.) and 25.20 (second degree poly.). All regressions include as control variables the baseline covariates presented on Table 1, Panel B. Standard errors are clustered on age measured in months and regressions include state and survey year fixed-effects. Significance: $* * *$ $\mathrm{p}<0.01, * * \mathrm{p}<0.05,{ }^{*} \mathrm{p}<0.1$.

\section{Concluding Remarks}

The interaction between the media and political institutions is a matter of great relevance to the current research agenda in political economy. Although a large literature about how the media affects outcomes such as turnout and civic engagement has been developed in the last decades, little attention has been paid to the opposite relation, i.e., how political institutions change the way citizens consume and relate to the media.

In this paper we document the effects of compulsory voting on information consumption. According to our model, citizens may acquire information in order to manifest their political preferences in the way that best represents their interests. We find that, citizens exposed to abstention penalties for the first time increase their probability to watch Jornal Nacional, Brazil's most trusted newscast, in 13.6\%. We also find that, when the sample is split between poor and rich voters, only the first group present robust effects across different specifications. Moreover, the impact of the compulsory voting law on the demand for information is stronger for those who have neutral attitudes towards the incumbent government. No impact is found for the consumption of other newscasts or non-journalistic TV shows. Finally, no impact is found at placebo cutoffs.

By employing an internally valid design to assess the effects of compulsory voting on information acquisition, we shed new light on the relation between political institutions and the media. Ultimately, this paper shows that, by increasing turnout, we are also nudging citizens into becoming more informed. Even though we cannot evaluate whether voters are actually learning new information and increasing political knowledge, the results show that voters are interested in acquiring information. Our results 
suggest that CV might be more successful when combined with policies that increase the availability of low cost and credible sources of information. 


\section{References}

Alt, J. E., J. Marshall, and D. D. Lassen (2016). Credible sources and sophisticated voters: When does new information induce economic voting? The Journal of Politics 78(2), 327-342.

Birch, S. (2009). Full participation: A comparative study of compulsory voting. Manchester University Press.

Calonico, S., M. D. Cattaneo, and R. Titiunik (2014). Robust nonparametric confidence intervals for regression-discontinuity designs. Econometrica 82(6), 2295-2326.

Cepaluni, G. and F. D. Hidalgo (2016). Compulsory voting can increase political inequality: Evidence from brazil. Political Analysis 24(2), 273-280.

Chiang, C.-F. and B. Knight (2011). Media bias and influence: Evidence from newspaper endorsements. The Review of Economic Studies, 1-26.

Ciochetto, L. (2013). Globalisation and Advertising in Emerging Economies: Brazil, Russia, India and China, Volume 51. Routledge.

de Leon, F. L. L. and R. Rizzi (2014). A test for the rational ignorance hypothesis: Evidence from a natural experiment in brazil. American Economic Journal: Economic Policy 6(4), 380-398.

de Leon, F. L. L. and R. Rizzi (2016). Does forced voting result in political polarization? Public Choice 166(1-2), 143-160.

Degan, A. (2006). Policy positions, information acquisition and turnout. The Scandinavian Journal of Economics 108(4), 669-682.

DellaVigna, S. and E. L. Ferrara (2015). Economic and social impacts of the media. Technical report, National Bureau of Economic Research.

DellaVigna, S. and E. D. Kaplan (2007). The fox news effect: Media bias and voting. The Quarterly Journal of Economics 122(3), 1187-1234.

DellaVigna, S., J. A. List, U. Malmendier, and G. Rao (2017). Voting to tell others. The Review of Economic Studies 84(1), 143-181.

Enikolopov, R., M. Petrova, and E. Zhuravskaya (2011). Media and political persuasion: Evidence from russia. The American Economic Review, 3253-3285.

Fava, A. C. P. e. and M. P. Arends-Kuenning (2013). Intrahousehold bargaining and the demand for consumer durables in brazil. Technical report, Discussion Paper Series, Forschungsinstitut zur Zukunft der Arbeit.

Fowler, A. (2013). Electoral and policy consequences of voter turnout: Evidence from compulsory voting in australia. Quarterly Journal of Political Science 8(2), 159-182.

Frandsen, B. R. (2013). Party bias in union representation elections: Testing for manipulation in the regression discontinuity design when the running variable is discrete. Mimeo, Brigham Young University. 
Funk, P. (2010). Social incentives and voter turnout: evidence from the swiss mail ballot system. Journal of the European Economic Association 8(5), 1077-1103.

Gelman, A. and G. Imbens (2014). Why high-order polynomials should not be used in regression discontinuity designs. Nber working papers, National Bureau of Economic Research.

Gentzkow, M. (2006). Television and voter turnout. The Quarterly Journal of Economics, 931-972.

Gerber, A. S., D. P. Green, and C. W. Larimer (2008). Social pressure and voter turnout: Evidence from a large-scale field experiment. American Political Science Review 102(01), 33-48.

Gordon, S. B. and G. M. Segura (1997). Cross-national variation in the political sophistication of individuals: Capability or choice? The Journal of Politics 59(01), 126-147.

Grosser, J. and M. Seebauer (2016). The curse of uninformed voting: An experimental study. Games and Economic Behavior 97, 205-226.

Holbein, J. B. and M. A. Rangel (2016). Does voting have upstream and downstream consequences? evidence from compulsory voting in brazil.

Kennedy, P. and A. Prat (2017). Where do people get their news? Mimeo, Columbia University.

La Ferrara, E., A. Chong, and S. Duryea (2012). Soap operas and fertility: Evidence from brazil. American Economic Journal: Applied Economics, 1-31.

Lee, D. S. and D. Card (2008). Regression discontinuity inference with specification error. Journal of Econometrics 142(2), 655-674.

Lee, D. S. and T. Lemieux (2010). Regression discontinuity designs in economics. Journal of Economic Literature 48, 281-355.

León, G. (2017). Turnout, political preferences and information: Experimental evidence from perú. Journal of Development Economics 127, 56-71.

Lijphart, A. (1997). Unequal participation: Democracy's unresolved dilemma presidential address, american political science association, 1996. American political science review 91(01), 1-14.

Loewen, P. J., H. Milner, and B. M. Hicks (2008). Does compulsory voting lead to more informed and engaged citizens? an experimental test. Canadian Journal of Political Science 41(03), 655-672.

Mainwaring, S. (1999). Rethinking party systems in the third wave of democratization: the case of Brazil. Stanford University Press.

Mainwaring, S., T. Scully, et al. (1995). Building democratic institutions: Party systems in Latin America. Stanford University Press Stanford.

Martinelli, C. (2006). Would rational voters acquire costly information? Journal of Economic Theory $129(1), 225-251$.

McCrary, J. (2008). Manipulation of the running variable in the regression discontinuity design: A density test. Journal of Econometrics 142(2), 698-714.

Mesquita, N. (2010a). Jornal nacional, democracia e confiança nas instituições democráticas. Democracia e Confiança: por que os cidadãos desconfiam das instituições públicas, 185-216. 
Mesquita, N. C. (2010b). Mídia noticiosa e adesão democrática: O papel de fontes secundárias de notícias. Cadernos do NUPPs 2.

Moisés, J. Á. (2010). Democracia e confiança: por que os cidadãos desconfiam das instituições públicas. São Paulo: Edusp.

Oberholzer-Gee, F. and J. Waldfogel (2009). Media markets and localism: Does local news en español boost hispanic voter turnout? American Economic Review 99(5), 2120-28.

Porto, M. (2007a). Tv news and political change in brazil the impact of democratization on tv globo's journalism. Journalism 8(4), 363-384.

Porto, M. P. (2007b). Framing controversies: television and the 2002 presidential election in brazil. Political Communication 24(1), 19-36.

Power, T. J. (2009). Compulsory for whom? mandatory voting and electoral participation in brazil, 1986-2006. Journal of Politics in Latin America 1(1), 97-122.

Saunders, B. (2012). The democratic turnout 'problem'. Political Studies 60(2), 306-320.

Shineman, V. A. (2016). If you mobilize them, they will become informed: experimental evidence that information acquisition is endogenous to costs and incentives to participate. British Journal of Political Science, 1-23.

Shineman, V. A. (2017). Costly extremism: Increasing the cost of voting deters participation among moderates, and generates a voting population dominated by extremists.

Singh, S. P. (2016). Elections as poorer reflections of preferences under compulsory voting. Electoral Studies 44, 56-65.

Sobbrio, F. (2014). The political economy of news media: theory, evidence and open issues. A Handbook of Alternative Theories of Public Economics, 278.

Zaller, J. (1992). The nature and origins of mass opinion. Cambridge university press.

Zucco Jr, C. and B. E. Lauderdale (2011). Distinguishing between influences on brazilian legislative behavior. Legislative Studies Quarterly 36(3), 363-396. 


\section{Appendix}

Figure A1: Trust in different sources of information for young individuals (TV versus traditional media).

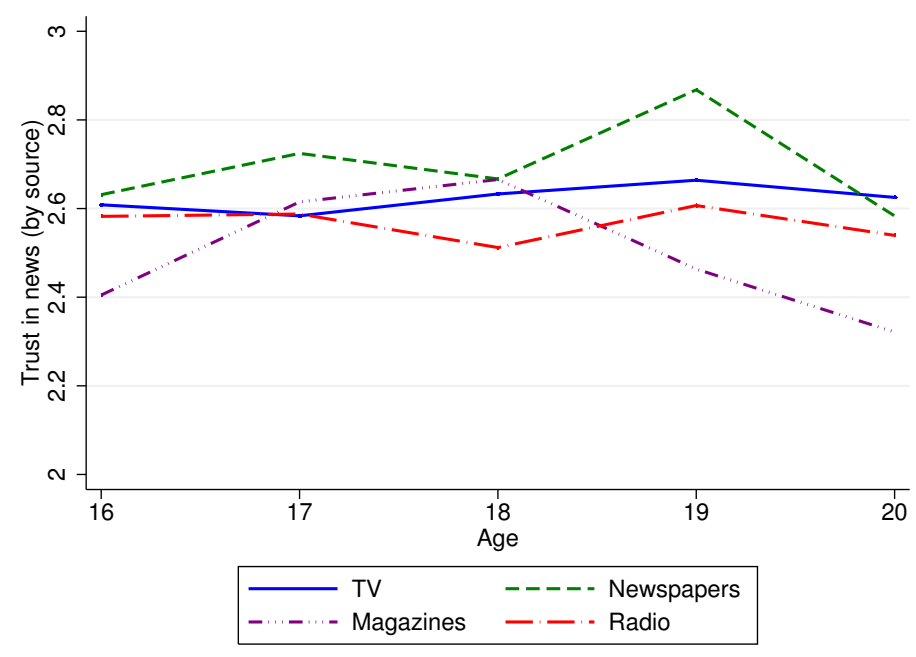

Notes: Trust level taken from the answer to the question "How much do you trust news from a given media outlet?" where answers are coded in the following way: 1 - Never, 2 - Few times, 3 - Many times, 4 - Always. Data from the Brazilian Media Survey 2015.

Figure A2: Trust in different sources of information for young individuals (TV versus online media).

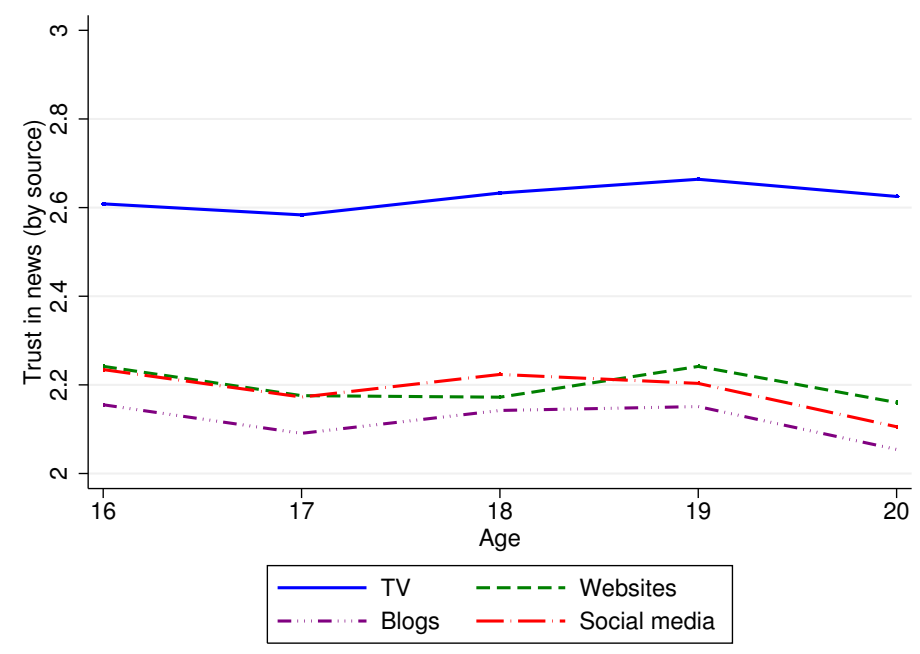

Notes: Trust level taken from the answer to the question "How much do you trust news from a given media outlet?" where answers are coded in the following way: 1 - Never, 2 - Few times, 3 - Many times, 4 - Always. Data from the Brazilian Media Survey 2015 
Figure A3: Histogram of the running variable.

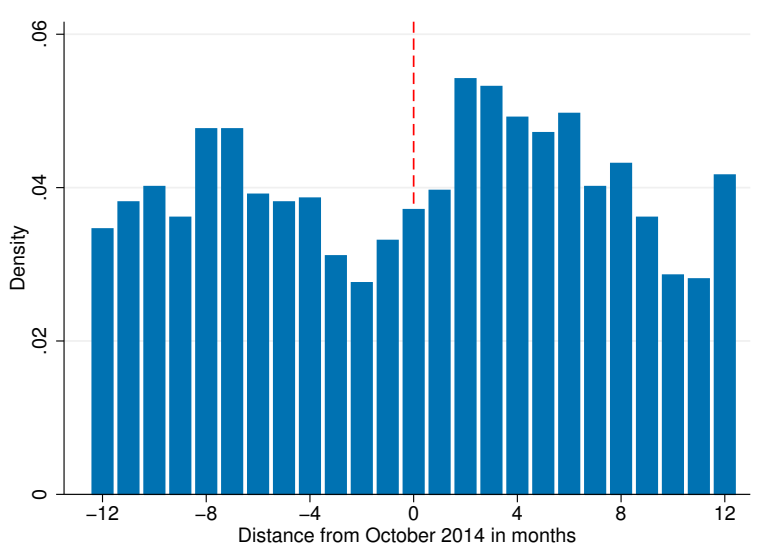

Notes: Running variable is the age of the individuals measured in months centered at October 2014. 
Table A1: Treatment effect of exposure to abstention penalties on the consumption of Jornal Nacional at the 70th birthday cutoff.

\begin{tabular}{|c|c|c|c|c|c|c|c|}
\hline Polynomial order & (1) & (2) & (3) & (4) & (5) & (6) & (7) \\
\hline \multirow[t]{2}{*}{ Zero } & 0.130 & 0.187 & 0.114 & 0.149 & 0.103 & 0.109 & 0.131 \\
\hline & $(0.051)^{* *}$ & $(0.312)$ & $(0.090)$ & $(0.074)^{*}$ & $(0.061)^{*}$ & $(0.050)^{* *}$ & $(0.044)^{* * *}$ \\
\hline \multirow[t]{2}{*}{ First } & 0.155 & 0.451 & 0.199 & 0.088 & 0.140 & 0.092 & 0.055 \\
\hline & $(0.061)^{* *}$ & $(0.479)$ & $(0.223)$ & $(0.156)$ & $(0.132)$ & $(0.114)$ & $(0.100)$ \\
\hline \multirow[t]{2}{*}{ Second } & 0.065 & 0.585 & 0.225 & 0.210 & 0.106 & 0.193 & 0.183 \\
\hline & $(0.075)$ & $(0.940)$ & $(0.403)$ & $(0.277)$ & $(0.237)$ & $(0.185)$ & $(0.161)$ \\
\hline Mean D.V. for $M_{i}=0$ & - & 0.480 & 0.478 & 0.445 & 0.464 & 0.448 & 0.424 \\
\hline Observations & - & 68 & 180 & 283 & $\begin{array}{l}.404 \\
378\end{array}$ & $\begin{array}{l}482 \\
482-10\end{array}$ & 603 \\
\hline Bandwidth & $\mathrm{CCT}$ & $\pm 4 \mathrm{mos}$ & \pm 8 mos. & \pm 12 mos. & $\pm 16 \mathrm{mos}$ & \pm 20 mos. & $\pm 24 \mathrm{mos}$ \\
\hline
\end{tabular}

Notes: Each figure in the table is from a separate local regression with the specified bandwidth and polynomial. The dependent variable is an indicator which takes value 1 whenever the respondent says that Jornal Nacional is one of the three TV shows that he or she watches the most during the week. Sample consists of literate citizens who responded the Brazilian Media Survey at the years of 2013 and 2014. All standard errors are clustered on age measured in months and all regressions include state and survey year fixed-effects. Significance: *** $\mathrm{p}<0.01$, $*^{*} \mathrm{p}<0.05, * \mathrm{p}<0.1$ 
Table A2: Income heterogeneous treatment effect of exposure to abstention penalties on the consumption of Jornal Nacional at the 70th birthday cutoff.

\begin{tabular}{|c|c|c|c|c|c|c|}
\hline Polynomial order & (1) & (2) & (3) & (4) & (5) & (6) \\
\hline \multicolumn{7}{|l|}{ Panel A: Low income } \\
\hline Zero & $\begin{array}{c}0.608 \\
(0.650)\end{array}$ & $\begin{array}{c}0.207 \\
(0.205)\end{array}$ & $\begin{array}{l}-0.016 \\
(0.193)\end{array}$ & $\begin{array}{c}0.015 \\
(0.134)\end{array}$ & $\begin{array}{c}0.023 \\
(0.095)\end{array}$ & $\begin{array}{c}0.080 \\
(0.077)\end{array}$ \\
\hline \multirow[t]{2}{*}{ First } & 0.191 & 0.698 & 0.515 & 0.194 & 0.063 & -0.025 \\
\hline & $(1.866)$ & $(0.454)$ & $(0.387)$ & $(0.284)$ & $(0.277)$ & $(0.229)$ \\
\hline \multirow[t]{2}{*}{ Second } & -1.000 & 0.531 & 0.557 & 0.728 & 0.478 & 0.386 \\
\hline & $(0.000)^{* * *}$ & $(0.873)$ & $(0.625)$ & $(0.500)$ & $(0.396)$ & $(0.337)$ \\
\hline \multirow{3}{*}{$\begin{array}{c}\text { Mean D.V. for } M_{i}=0 \\
\text { Observations } \\
\text { Bandwidth }\end{array}$} & 0.392 & 0.472 & 0.490 & 0.449 & 0.447 & 0.405 \\
\hline & 32 & 88 & 141 & 189 & 249 & 310 \\
\hline & $\pm 4 \mathrm{mos}$ & $\pm 8 \mathrm{mos}$ & $\pm 12 \mathrm{mos}$ & \pm 16 mos. & \pm 20 mos. & \pm 24 mos. \\
\hline \multicolumn{7}{|l|}{ Panel B: High income } \\
\hline Zero & 0.044 & 0.068 & 0.268 & 0.185 & 0.197 & 0.193 \\
\hline \multirow[t]{2}{*}{ First } & -0.352 & $\begin{array}{l}(0.152) \\
-0.013\end{array}$ & $\begin{array}{l}(0.121) \\
-0.124\end{array}$ & 0.125 & $\begin{array}{c}(0.085) \\
0.112\end{array}$ & $\begin{array}{c}(0.070) \\
0.134\end{array}$ \\
\hline & $(1.026)$ & $(0.405)$ & $(0.216)$ & $(0.160)$ & $(0.160)$ & $(0.143)$ \\
\hline Second & $\begin{array}{c}3.529 \\
(0.568)^{* * *}\end{array}$ & $\begin{array}{c}0.186 \\
(0.642)\end{array}$ & $\begin{array}{l}-0.076 \\
(0.393)\end{array}$ & $\begin{array}{c}-0.309 \\
(0.308)\end{array}$ & $\begin{array}{c}-0.066 \\
(0.238)\end{array}$ & $\begin{array}{c}0.018 \\
(0.207)\end{array}$ \\
\hline Mean D.V. for $M_{i}=0$ & 0.518 & 0.482 & 0.407 & 0.476 & 0.448 & 0.440 \\
\hline Observations & 36 & 92 & 142 & 189 & 233 & 293 \\
\hline Bandwidth & \pm 4 mos. & \pm 8 mos. & \pm 12 mos. & \pm 16 mos. & $\pm 20 \mathrm{mos}$ & $\pm 24 \mathrm{mos}$ \\
\hline
\end{tabular}

Notes: Each figure in the table is from a separate local regression with the specified bandwidth and polynomial. The dependent variable is an indicator which takes value 1 whenever the respondent says that Jornal Nacional is one of the three TV shows that he or she watches the most during the week. Sample consists of literate citizens who responded the Brazilian Media Survey at the years of 2013 an 2014. The median household income is two minimum wages. Panel A contains the ITT estimates for the subpopulation with income below or equal to the median. Panel B contains the ITT estimates for the subpopulation with income above the median. All standard errors are clustered on age measured in months and all regressions include state and survey year fixed-effects. Significance: *** $\mathrm{p}<0.01, * *$ $\mathrm{p}<0.05,{ }^{*} \mathrm{p}<0.1$ 
Table A3: Heterogeneous treatment effect of exposure to abstention penalties on the consumption of Jornal Nacional at the 70th birthday cutoff.

\begin{tabular}{|c|c|c|c|c|c|c|}
\hline Polynomial order & $(1)$ & $(2)$ & $(3)$ & $(4)$ & $(5)$ & $(6)$ \\
\hline \multicolumn{7}{|c|}{ Panel A: DV = Neutral (dummy) } \\
\hline Zero & $\begin{array}{c}0.160 \\
(0.116)\end{array}$ & $\begin{array}{l}-0.000 \\
(0.058)\end{array}$ & $\begin{array}{l}-0.053 \\
(0.040)\end{array}$ & $\begin{array}{l}-0.054 \\
(0.052)\end{array}$ & $\begin{array}{l}-0.032 \\
(0.046)\end{array}$ & $\begin{array}{l}-0.009 \\
(0.039)\end{array}$ \\
\hline First & $\begin{array}{c}0.399 \\
(0.200)\end{array}$ & $\begin{array}{c}0.238 \\
(0.112)^{*}\end{array}$ & $\begin{array}{c}0.102 \\
(0.078)\end{array}$ & $\begin{array}{c}0.003 \\
(0.091)\end{array}$ & $\begin{array}{l}-0.065 \\
(0.062)\end{array}$ & $\begin{array}{l}-0.090 \\
(0.058)\end{array}$ \\
\hline Second & $\begin{array}{c}1.329 \\
(0.469)^{* *}\end{array}$ & $\begin{array}{c}0.445 \\
(0.231)^{*}\end{array}$ & $\begin{array}{c}0.235 \\
(0.097)^{* *}\end{array}$ & $\begin{array}{c}0.266 \\
(0.112)^{* *}\end{array}$ & $\begin{array}{c}0.138 \\
(0.091)\end{array}$ & $\begin{array}{c}0.048 \\
(0.095)\end{array}$ \\
\hline $\begin{array}{c}\text { Mean D.V. for } M_{i}=0 \\
\text { Observations } \\
\text { Bandwidth }\end{array}$ & $\begin{array}{l}0.407 \\
\quad 75 \\
\pm 4 \mathrm{mos}\end{array}$ & $\begin{array}{c}0.448 \\
199 \\
\pm 8 \mathrm{mos}\end{array}$ & $\begin{array}{c}0.501 \\
317 \\
\pm 12 \mathrm{mos}\end{array}$ & $\begin{array}{c}0.483 \\
426 \\
\pm 16 \mathrm{mos} .\end{array}$ & $\begin{array}{c}0.485 \\
549 \\
\pm 20 \mathrm{mos}\end{array}$ & $\begin{array}{c}0.467 \\
694 \\
\pm 24 \mathrm{mos}\end{array}$ \\
\hline \multicolumn{7}{|c|}{ Panel B: DV = Polarized (dummy) } \\
\hline Zero & $\begin{array}{l}-0.160 \\
(0.116)\end{array}$ & $\begin{array}{c}0.000 \\
(0.058)\end{array}$ & $\begin{array}{c}0.053 \\
(0.040)\end{array}$ & $\begin{array}{c}0.054 \\
(0.052)\end{array}$ & $\begin{array}{c}0.032 \\
(0.046)\end{array}$ & $\begin{array}{c}0.009 \\
(0.039)\end{array}$ \\
\hline First & $\begin{array}{l}-0.399 \\
(0.200)\end{array}$ & $\begin{array}{c}-0.238 \\
(0.112)^{*}\end{array}$ & $\begin{array}{c}-0.102 \\
(0.078)\end{array}$ & $\begin{array}{l}-0.003 \\
(0.091)\end{array}$ & $\begin{array}{c}0.065 \\
(0.062)\end{array}$ & $\begin{array}{c}0.090 \\
(0.058)\end{array}$ \\
\hline Second & -1.329 & -0.445 & -0.235 & -0.266 & -0.138 & -0.048 \\
\hline Mean D.V. for $M_{i}=0$ & 0.593 & 0.552 & 0.499 & 0.517 & 0.515 & 0.532 \\
\hline Observations & 75 & 199 & 317 & 426 & 549 & 694 \\
\hline Bandwidth & \pm 4 mos. & $\pm 8 \mathrm{mos}$ & $\pm 12 \operatorname{mos}$ & \pm 16 mos. & \pm 20 mos. & \pm 24 mos. \\
\hline
\end{tabular}

Notes: Each figure in the table is from a separate local regression with the specified bandwidth and polynomial. The dependent variable is an indicator which takes value 1 whenever the respondent says that Jornal Nacional is whe citizens age measured in months and all regressions include state and survey year fixed-effects. Significance: $* * * \mathrm{p}<0.01$, $* * \mathrm{p}<0.05, * \mathrm{p}<0.1$. 
Table A4: Government evaluation heterogeneous treatment effect of exposure to abstention penalties on the consumption of Jornal Nacional at the 70th birthday cutoff.

\begin{tabular}{|c|c|c|c|c|c|c|}
\hline Polynomial order & (1) & (2) & (3) & (4) & (5) & (6) \\
\hline \multicolumn{7}{|l|}{ Panel A: Neutral } \\
\hline Zero & $\begin{array}{l}-0.140 \\
(0.962)\end{array}$ & $\begin{array}{c}0.270 \\
(0.167)\end{array}$ & $\begin{array}{c}0.283 \\
(0.104)^{* *}\end{array}$ & $\begin{array}{c}0.280 \\
(0.085)^{* * *}\end{array}$ & $\begin{array}{c}0.226 \\
(0.086)^{* *}\end{array}$ & $\begin{array}{c}0.248 \\
(0.072)^{* * *}\end{array}$ \\
\hline First & $\begin{array}{c}0.660 \\
(0.375)\end{array}$ & $\begin{array}{l}-0.263 \\
(0.520)\end{array}$ & $\begin{array}{c}0.120 \\
(0.311)\end{array}$ & $\begin{array}{c}0.238 \\
(0.244)\end{array}$ & $\begin{array}{c}0.205 \\
(0.201)\end{array}$ & $\begin{array}{c}0.170 \\
(0.162)\end{array}$ \\
\hline Second & $\begin{array}{c}-3.333 \\
(0.000)^{* * *}\end{array}$ & $\begin{array}{l}-0.784 \\
(0.719)\end{array}$ & $\begin{array}{l}-0.197 \\
(0.612)\end{array}$ & $\begin{array}{c}0.087 \\
(0.480)\end{array}$ & $\begin{array}{c}0.178 \\
(0.409)\end{array}$ & $\begin{array}{c}0.255 \\
(0.345)\end{array}$ \\
\hline $\begin{array}{c}\text { Mean D.V. for } M_{i}=0 \\
\text { Observations } \\
\text { Bandwidth }\end{array}$ & $\begin{array}{l}0.529 \\
31 \\
\pm 4 \text { mos. }\end{array}$ & $\begin{array}{c}0.458 \\
81 \\
\pm 8 \mathrm{mos}\end{array}$ & $\begin{array}{c}0.438 \\
128 \\
\pm 12 \mathrm{mos}\end{array}$ & $\begin{array}{c}0.431 \\
166 \\
\pm 16 \mathrm{mos}\end{array}$ & $\begin{array}{c}0.431 \\
218 \\
\pm 20 \mathrm{mos}\end{array}$ & $\begin{array}{c}0.431 \\
271 \\
\pm 24 \mathrm{mos}\end{array}$ \\
\hline \multicolumn{7}{|l|}{ Panel B: Polarized } \\
\hline Zero & $\begin{array}{c}0.127 \\
(0.393)\end{array}$ & $\begin{array}{l}-0.013 \\
(0.124)\end{array}$ & $\begin{array}{c}0.025 \\
(0.091)\end{array}$ & $\begin{array}{l}-0.027 \\
(0.073)\end{array}$ & $\begin{array}{c}0.004 \\
(0.062)\end{array}$ & $\begin{array}{c}0.030 \\
(0.059)\end{array}$ \\
\hline First & $\begin{array}{c}0.883 \\
(0.704)\end{array}$ & $\begin{array}{c}0.154 \\
(0.291)\end{array}$ & $\begin{array}{c}0.069 \\
(0.188)\end{array}$ & $\begin{array}{c}0.049 \\
(0.172)\end{array}$ & $\begin{array}{l}-0.032 \\
(0.142)\end{array}$ & $\begin{array}{l}-0.052 \\
(0.122)\end{array}$ \\
\hline Second & $\begin{array}{c}2.185 \\
(1.629)\end{array}$ & $\begin{array}{c}0.711 \\
(0.438)\end{array}$ & $\begin{array}{c}0.404 \\
(0.264)\end{array}$ & $\begin{array}{c}0.151 \\
(0.225)\end{array}$ & $\begin{array}{c}0.215 \\
(0.212)\end{array}$ & $\begin{array}{c}0.107 \\
(0.193)\end{array}$ \\
\hline Mean D.V. for $M_{i}=0$ & 0.447 & 0.501 & 0.470 & 0.515 & 0.480 & 0.426 \\
\hline Observations & 37 & 97 & 152 & 207 & 258 & 326 \\
\hline Bandwidth & \pm 4 mos. & \pm 8 mos. & $\pm 12 \mathrm{mos}$ & \pm 16 mos. & \pm 20 mos. & \pm 24 mos. \\
\hline
\end{tabular}

Notes: Each figure in the table is from a separate local regression with the specified bandwidth and polynomial. The dependent variable is an indicator which takes value 1 whenever the respondent says
that Jornal Nacional is one of the three TV shows that he or she watches the most during the week. Sample consists of literate citizens who responded the Brazilian Media Survey at the years of 2013 and Sample consists of literate citizens who responded the Brazilian Media Survey at the years of 2013 and
2014 . All standard errors are clustered on age measured in months and all regressions include state and survey year fixed-effects. Significance: $* * * \mathrm{p}<0.01,{ }^{* *} \mathrm{p}<0.05,{ }^{*} \mathrm{p}<0.1$ 